University of Nebraska - Lincoln

DigitalCommons@University of Nebraska - Lincoln 


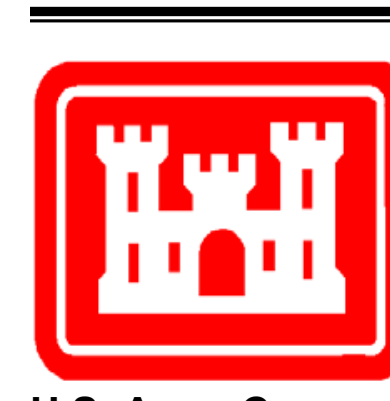

U.S. Army Corps of Engineers Omaha District

\section{A SCOPING STUDY OF WATER QUALITY CONDITIONS IN THE MISSOURI NATIONAL RECREATIONAL RIVER REACH FROM NEAR GAVINS POINT DAM TO PONCA STATE PARK, NEBRASKA}

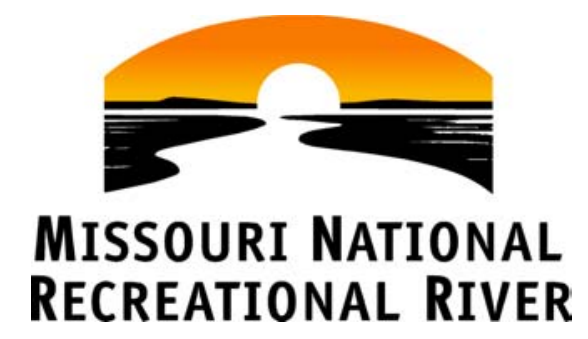

March 2002 



\section{A SCOPING STUDY OF WATER QUALITY CONDITIONS IN THE MISSOURI NATIONAL RECREATIONAL RIVER REACH FROM NEAR GAVINS POINT DAM TO PONCA STATE PARK, NEBRASKA}

\section{Prepared by:}

Water Quality Unit

Water Control and Water Quality Section Hydrologic Engineering Branch

Engineering Division

Omaha District

U.S. Army Corps of Engineers 
For Information Regarding This Report Please Contact:

Dave Jensen

U.S. Army Corps of Engineers, Omaha District

Attention: CENWO-ED-HA

106 South $15^{\text {th }}$ Street

Omaha, Nebraska 68192-1618

(402) 221-4622

david.e.jensen@usace.army.mil 


\section{TABLE OF CONTENTS}

Page

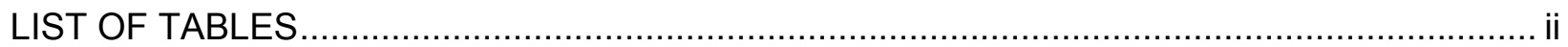

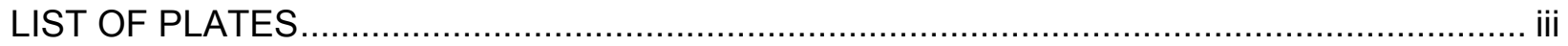

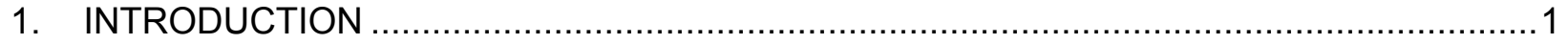

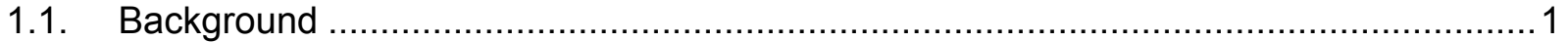

1.1.1. Wild and Scenic Rivers Act Provisions ........................................................ 1

1.1.2. Endangered Species Act and Biological Opinion Provisions .............................. 1

1.1.3. Nebraska Water Quality Standards Provisions ............................................... 3

1.2. Water Quality Considerations ...........................................................................

1.2.1. Need for Water Quality Data in the MNRR Reach .......................................... 3

1.2.2. Water Quality Scoping Study ……………............................................

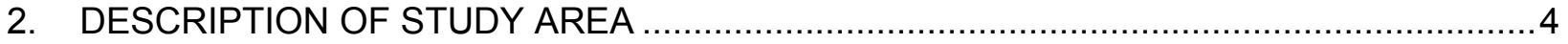

2.1. Surface Water Hydrology ............................................................................ 4

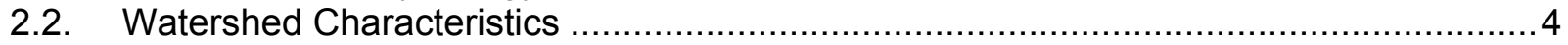

2.3. Water Quality Conditions And Concerns Identified In State 305(b) Reports ..................5

2.3.1. Missouri River (MNRR Reach) ............................................................

2.3.1.1. James River Basin (South Dakota) ………….....................................

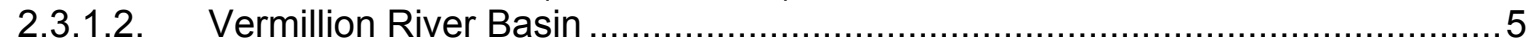

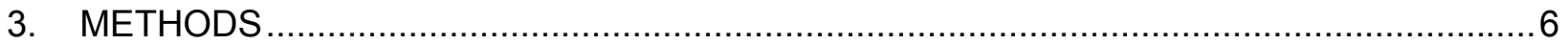

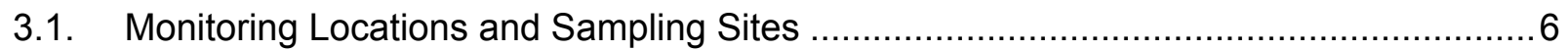

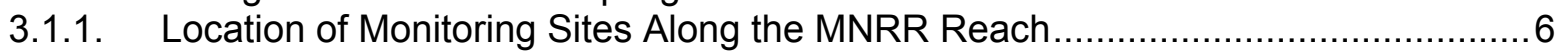

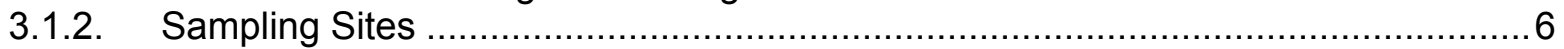

3.2. Determination Of Water Quality Conditions ………..........................................

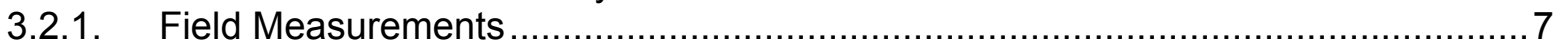

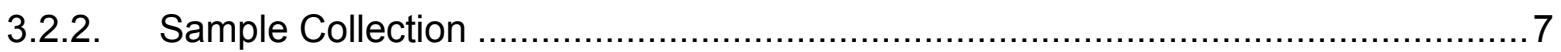

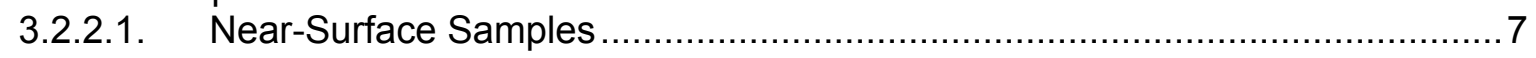

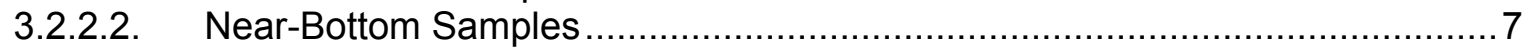

3.2.3. Laboratory Analysis and Sample Preservation ............................................ 7

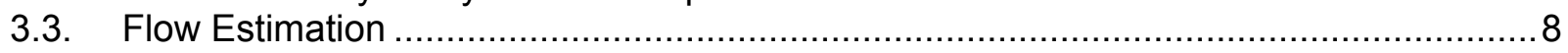

3.4. Assessment Of Water Quality Data .................................................................

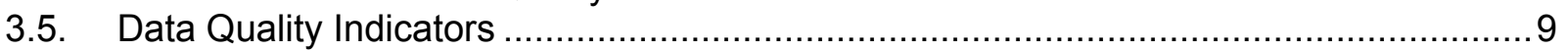

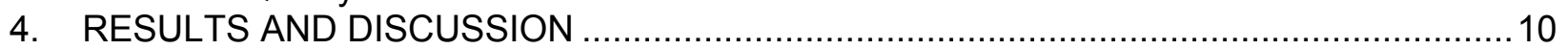

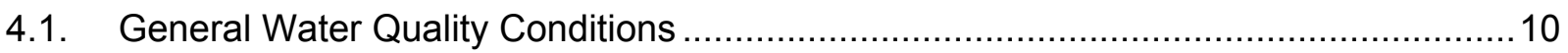

4.2. Longitudinal Variation In Water Quality …………........................................... 10

4.3. Localized Variation In Water Quality …………............................................... 11

4.3.1. Near-Surface Versus Near-Bottom Thalweg Sites ......................................... 11

4.3.2. Thalweg Versus Backwater Sites ..............................................................11

4.4. Effects Of The James And Vermillion Rivers On Turbidity In The Missouri River ........12

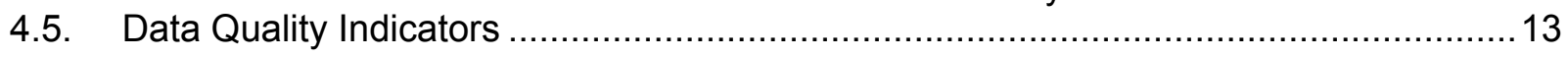

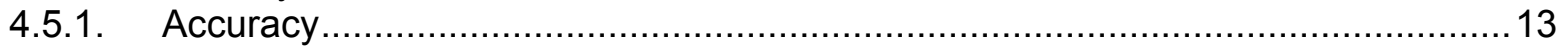

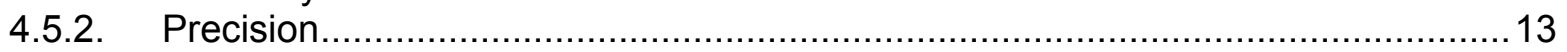

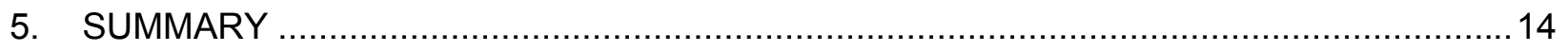

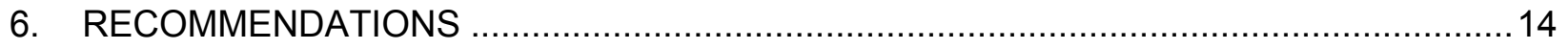

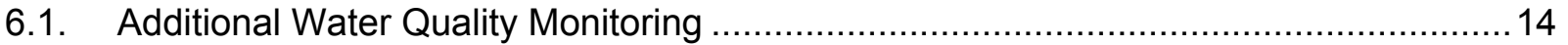

6.2. Water Quality Management Concerns .................................................................. 15

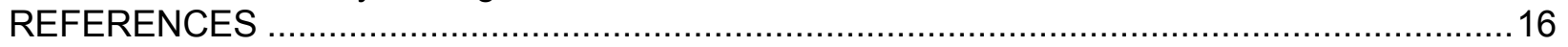




\section{LIST OF TABLES}

Page

Table 1. 8-Digit Hydrologic Units (HUCs) that make up the watershed, below Gavins Point Dam, of the MNRR reach

Table 2. Analytical method, method detection limit, and reporting limit for parameters analyzed in the WES Laboratory

Table 3. Mean daily discharge calculated for 5 gaging sites in proximity to the MNRR reach for the period August 17 through September 26, 2001

Table 4. Water balance based on the mean daily discharges calculated at the 5 gage sites for the period August 17 through September 26, 2001

Table 5. Summary statistics of water quality conditions monitored at the near-surface thalweg and tributary sites during the scoping study....

Table 6. Mean turbidity, Secchi depth, and conductivity values determined from data collected at Sites 2Ts, 3, 3T1, 3T2, 3T3, 3T4, 4B, 5Ts, 6, 7Ts, and 8Ts during the scoping study

Table 7. Total suspended solids loading estimates for the James and Vermillion Rivers for selected days during the scoping study

Table 8. Analysis results and percent relative difference (RPD) of collocated samples collected during the scoping study..... 


\section{LIST OF PLATES}

Page

Plate 1. Location of the Missouri National Recreational River (MNRR) reach within the Omaha District.

Plate 2. Watershed area draining to the MNRR reach below Gavins Point Dam as delineated by 8-digit Hydrologic Units (HUCs).

Plate 3. Location of monitoring sites along the MNRR reach where water quality samples were collected as part of the scoping study.

Plate 4. Location of Site 1 based on the average of the obtained GPS coordinates and projected on a 1997 orthophoto of the area

Plate 5. Location of Sites 2B, 2T, 3, 3T1, 3T2, 3T3, 3T4, 4B, and 4T based on the average of the obtained GPS coordinates and projected on a 1997 orthophoto of the area.

Plate 6. Location of Sites 5B, 5T, 6, 7B, and 7T based on the average of the obtained GPS coordinates and projected on a 1997 orthophoto of the area

Plate 7. Location of Sites 8B and 8T based on the average of the obtained GPS coordinates and projected on a 1997 orthophoto of the area

Plate 8. Location of gaging stations along and in proximity to the MNRR reach.....

Plate 9. Box plots of water quality parameters monitored at Sites 1Ts, 2Ts, 5Ts, and 8Ts during the scoping study

Plate 10. Box plots of turbidity and total suspended solids levels for the near-bottom and near-surface thalweg samples collected at monitoring location 1

Plate 11. Box plots of turbidity, total suspended solids, and chlorophyll a levels for the backwater and near-bottom and near-surface thalweg samples collected at monitoring location 2

Plate 12. Box plots of turbidity, total suspended solids, and chlorophyll a levels for the backwater and near-bottom and near-surface thalweg samples collected at monitoring location 4

Plate 13. Box plots of turbidity, total suspended solids, and chlorophyll a levels for the backwater and near-bottom and near-surface thalweg samples collected at monitoring location 5

Plate 14. Box plots of turbidity, total suspended solids, and chlorophyll a levels for the backwater and near-bottom and near-surface thalweg samples collected at monitoring location 7 


\section{LIST OF PLATES (Continued)}

Page

Plate 15. Box plots of turbidity, total suspended solids, and chlorophyll a levels for the backwater and near-bottom and near-surface thalweg samples collected at monitoring location 8

Plate 16. Area near the mouth of the James River as it enters a side channel of the Missouri River as depicted in a 1997 orthophoto of the area 


\section{INTRODUCTION}

The unchannelized reach of the Missouri River below Gavins Point Dam has several ongoing water resource management issues that involve and affect the U.S. Army Corps of Engineers (Corps). Water quality management considerations are of particular importance to three issues: 1) management of a portion of the reach as a recreational river under the Federal Wild and Scenic Rivers Act, 2) the reach is included in an action area identified by the U.S. Fish and Wildlife Service (USFWS) under the Federal Endangered Species Act (ESA) for three species (pallid sturgeon, least tern, and piping plover) identified as being in jeopardy, and 3) the State of Nebraska has given the reach Tier 3 protection under the antidegradation provisions of the state's water quality standards and Federal Clean Water Act (CWA). To facilitate identification of water quality management concerns and information needs regarding these issues, the Omaha District's Water Quality Unit (ODWQU) conducted a scoping study of water quality conditions on the portion of the reach from Gavins Point Dam to Ponca State Park, Nebraska.

\subsection{BACKGROUND}

\subsubsection{Wild and Scenic Rivers Act Provisions}

The approximate 57-mile reach of the Missouri River from about one-mile below Gavins Point Dam to Ponca State Park, Nebraska has been classified as a recreational river under the Federal Wild and Scenic Rivers Act. All the rivers in the Wild and Scenic System must be freeflowing and the related adjacent land must possess outstanding remarkable characteristics for at least one of the following: scenic, recreational, geologic, fish and wildlife, historic, cultural, or other similar values. The justification that supported that this reach of the Missouri River be protected as a recreational river identified its outstanding remarkable recreational, fish and wildlife, aesthetic, historical, and cultural values. The Secretary of the U.S. Department of Interior is mandated to administer the river in a manner that will protect and enhance these values for the benefit and enjoyment of present and future generations. Therefore, the recreational, fish and wildlife, aesthetic, historical, and cultural values that qualified the segment for designation are to be protected and enhanced. Plate 1 shows the location of the Missouri National Recreational River (MNRR) reach within the Omaha District.

The National Park Service (NPS) is designated as the overall administrator of the MNRR. In 1999, the Corps and the NPS jointly finalized an updated version of the General Management Plan (GMP) for the MNRR. The existing GMP, which was developed in 1980, was updated because of the identification of additional federally-designated threatened and endangered species that inhabited the reach. The new GMP provides a management strategy to protect and enhance the values for which the reach was designated as a recreational river, which includes "fish and wildlife" values. The NPS and the Corps manage the MNRR through a cooperative agreement with the NPS generally administering land-related resources and the Corps generally managing water-related resources. Bank stabilization is still a project component, primarily to protect the MNRR values.

\subsubsection{Endangered Species Act and Biological Opinion Provisions}

The Corps, in early 2000, requested that formal Section 7 consultation under the ESA begin with the USFWS on Corps projects affecting the Missouri River. An ESA Section 7 consultation addresses the effects of a Federal action on listed species and the ecosystem upon which they depend. An ecosystem-based consultation was conducted that addressed three 
listed bird species - bald eagle (threatened), Interior population of the least tern (endangered), and Northern Great Plains population of the piping plover (threatened); and one fish species pallid sturgeon (endangered). A Biological Opinion (BiOp) regarding the four evaluated species was issued concerning the continuing operation and maintenance of the following Missouri River Basin Corps projects:

- Missouri River Main Stem Reservoir System,

- Kansas River Tributary Reservoir System, and

- Maintenance of the Missouri River Bank Stabilization and Navigation Project.

The BiOp stated that the continuing operation of these projects is likely to jeopardize the continued existence of the least tern, piping plover, and pallid sturgeon, but is not likely to jeopardize the continued existence of the bald eagle.

Of the three species identified to be in jeopardy, water quality conditions have the most direct impact on the pallid sturgeon. Pallid sturgeon historically occupied warm, turbid river systems. Current research indicates that pallid sturgeon spawning is directly linked to water temperature - as water temperature increases to $16.7^{\circ}$ to $18.3^{\circ} \mathrm{C}\left(62^{\circ}\right.$ to $\left.65^{\circ} \mathrm{F}\right)$ pallid sturgeon initiate spawning activity (USFWS, 2000). Current operation of the Fort Peck, Garrison, and Fort Randall Dams with hypolimnetic hydropower releases, provides unsuitable colder water temperatures that negatively impact spawning by native river fishes, including the pallid sturgeon, and production at all trophic levels (USFWS, 2000). More suitable water temperatures for native fish spawning and invertebrate production exist in the free-flowing river below Gavins Point Dam. Pallid sturgeon avoid areas without turbidity and current (Bailey and Cross, 1954 and Erickson, 1992). Turbidity levels below all the Missouri River mainstem reservoirs have been significantly reduced from pre-impoundment conditions due to sediment trapping in the impounded reservoirs. Due to the long potential life span of pallid sturgeon (i.e., greater than 50 years), the fish is particularly susceptible to the bioaccumulation of pollutants that may contribute to early mortality and reduced reproductive viability. The BiOp stated the Corps was to consider the Missouri River reaches from Fort Peck Dam to Lake Sakakawea and from Gavins Point Dam to the Mississippi River as high priority segments for pallid sturgeon management efforts (USFWS, 2000). The reach from Gavins Point Dam to the Mississippi River was also one of four recovery priority management areas on the Missouri River identified by the Pallid Sturgeon Recovery Plan (USFWS, 1993) for priority implementation of recovery actions.

The BiOp stated that the Corps should adopt adaptive management as one tool to preclude jeopardy to least terns, piping plovers, and pallid sturgeon. The BiOp requested that the Corps: 1) evaluate the cumulative effects of bank stabilization, as permitted by the Corps, to determine to what extent continued stabilization is reducing sedimentation, turbidity, import of organic matter, and elimination of cut-bank habitat on the Missouri River; 2) evaluate the capability and practicality of increasing water temperature of the Missouri River in priority reaches during critical periods for native warm-water fish though adjustment of water discharge requirements for power plants and other industries; 3 ) research and develop a way to restore the dynamic equilibrium of sediment transport and associated turbidity in river reaches downstream of Fort Peck, Garrison, Fort Randall, and Gavins Point Dams; and 4) restore turbidity to functional levels downstream of Fort Peck, Fort Randall, and Gavins Point Dams. Given the water quality issues raised by the BiOp, the collection of targeted water quality data could greatly facilitate implementation of an adaptive management approach by the Corps. 


\subsubsection{Nebraska Water Quality Standards Provisions}

The MNRR reach has been designated by the State of Nebraska as a State Resource Water - Class A in its water quality standards (NDEQ, 2000). By Nebraska's definition, Class A State Resource Waters constitute an outstanding State or National resource, such as waters within national or state parks, national forests or wildlife refuges, and waters of exceptional recreational or ecological significance. These include waters that provide a unique habitat for federally designated endangered or threatened species and rivers designated under the Wild and Scenic Rivers Act. Designation of a waterbody as a Class A State Resource Water in Nebraska's water quality standards identifies that waterbody for Tier 3 protection under the state's antidegradation policy. Tier 3 protection as an Outstanding National Resource Water is also inferred to the MNRR reach under the Federal CWA's antidegradation provisions. The water quality implication of Tier 3 protection is that the existing water quality within the MNRR reach must be maintained and protected.

The CWA requires water quality to be maintained and protected in Tier 3 waters. The U.S. Environmental Protection Agency (EPA) has interpreted this provision to mean no new or increased discharges to Tier 3 waters and no new or increased discharge to tributaries of Tier 3 waters that would result in lower water quality in the Tier 3 waterbody. The only exception to this prohibition, as discussed in the preamble to the Water Quality Standards Regulation (48 F.R. 51402), permits States to allow some limited activities that result in temporary and shortterm changes in the water quality of Tier 3 waters. Such activities must not permanently degrade water quality or result in water quality lower than that necessary to protect the existing uses in the Tier 3 waterbody. The intent of EPA's provision clearly is to limit water quality degradation to the shortest time possible (USEPA, 1994).

\subsection{WATER QUALITY CONSIDERATIONS}

\subsubsection{Need for Water Quality Data in the MNRR Reach}

Water quality data is needed by the Corps in the MNRR reach to facilitate current and future efforts regarding: 1) the management of the reach as a recreational river, 2) enhancing riverine habitat in the reach for jeopardized species, and 3) management of water quality in the reach pursuant to the antidegradation provisions of the State of Nebraska's water quality standards and the CWA. Water quality conditions are intrinsic to the values for which the reach was designated a recreational river under the Wild and Scenic Rivers Act. Knowing baseline water quality conditions and how water quality may be changing due to anthropogenic influences is paramount to managing the water resource aspects of the recreational river. Water temperature, turbidity, nutrient cycling, and sediment transport are water quality factors that have been identified as concerns regarding the jeopardization of pallid sturgeon, least terns, and piping plovers in the Missouri River. Documenting existing water quality conditions in the MNRR will facilitate the evaluation of any implemented actions to enhance water quality conditions for jeopardized species in the reach. Gaining insights into whether pollutants could be impacting the pallid sturgeon population in this reach of the Missouri River is also important. Knowing existing water quality conditions for pertinent parameters is also needed to facilitate implementation of the Tier 3 antidegradation provisions applicable to the reach.

\subsubsection{Water Quality Scoping Study}

A preliminary review of water quality monitoring activities along the MNRR reach found limited historic and ongoing water quality sampling. The Corps is collecting water quality data at 
the Gavins Point Dam discharge. Although this sampling has occurred over a fairly lengthy time, the water quality parameters monitored are limited to water temperature, dissolved oxygen, $\mathrm{pH}$, and conductivity. The Nebraska Department of Environmental Quality (NDEQ) has sampled the Missouri River at Ponca State Park on a periodic basis (i.e., every 5 years) as part of its rotating river basin monitoring network. The City of Yankton utilizes the Missouri River as a drinking water source, and regularly monitors the "raw" river water for numerous water quality parameters. Water quality data to define temporal and spatial water quality conditions throughout the MNRR reach are generally lacking.

In an initial effort to begin addressing the water quality information needs for the MNRR reach, the ODWQU conducted a scoping study of water quality conditions within the reach. The monitoring objectives established for the scoping study were:

1) Define "baseline" water quality conditions for the period of the study.

2) Assess longitudinal variation in selected parameters from the upstream to downstream boundaries of the MNRR reach.

3) Assess "horizontal" (i.e. thalweg versus backwater) and "vertical" (i.e., near-surface versus near-bottom) variation of selected water quality parameters.

4) Assess the impact, if any, that the inflows of the James and Vermillion Rivers have on turbidity levels in the Missouri River. Estimate the suspended solids load being delivered by these tributary rivers to associate with measured turbidity levels in the Missouri River above and below the tributary inflows.

Monitoring for of the scoping study occurred over a 6-week period from late August through September 2001, and included the collection of water quality samples at 9 locations.

\section{DESCRIPTION OF STUDY AREA}

\subsection{SURFACE WATER HYDROLOGY}

The MNRR reach starts about one mile below Gavins Point dam and extends downstream to Ponca State Park in Nebraska; a distance of approximately 57 miles. Two major tributaries, the James and Vermillion Rivers, flow into the reach from South Dakota (Plate 2). Several small tributaries (Beaver Creek, Antelope Creek, Bow Creek, Ames Creek, Lime Creek, Deer Creek, Walnut Creek, Turkey Creek, and Gibbs Creek) flow into the reach from Nebraska.

\subsection{WATERSHED ChARACTERISTICS}

The 8-digit Hydrologic Units (HUCs) that make up the watershed of the MNRR reach below Gavins Point Dam are shown in Plate 2 and described in Table 1. The size of the watershed contributing runoff to the MNRR reach below Gavins Point Dam is approximately 25,120 square miles. Of the total 25,120 square mile watershed, approximately 21,590 square miles is in the James River watershed and approximately 2,650 square miles is in the Vermillion River watershed. Approximately 880 square miles is in the watersheds of the other tributaries discharging directly to the MNRR reach (mainly from tributaries in Nebraska). The coteau region, HUCs 10160007, 10160010, and 10170103 (2,530 square miles), are largely internally drained and generally non-contributing to surface water runoff within the watershed.

The predominate land use within the watershed is agricultural, with both cropland and livestock operations present. There are numerous industries in the James River basin, most which are related to agriculture (SDDENR, 1998). Major towns in the watershed include 
Vermillion, South Dakota (population 11,970), Yankton, South Dakota (14,330), Mitchell, South Dakota (14,390), Huron, South Dakota (17,180), Aberdeen, South Dakota $(24,870)$ and Jamestown, North Dakota $(15,570)$. All of these towns, except Vermillion, are in the James River basin.

\subsection{WATER QUALITY Conditions ANd CONCERnS IDENTIFIEd In StATE 305(B) ReportS}

\subsubsection{Missouri River (MNRR Reach)}

Assessment of water quality conditions in the MNRR reach of the Missouri River in state 305(b) reports is limited. The State of Nebraska's 2000 305(b) report indicates that water quality in the MNRR reach was relatively good for the assessed period. This was based on water quality samples collected in 1995 from the Missouri River at Ponca State Park (i.e., lower end of MNRR reach). The 1995 sampling indicated that fecal coliform bacteria concentrations were supportive of the designated recreational use, and concentrations of the herbicides atrazine and alachlor met acute and chronic water quality standards criteria.

\subsubsection{James River Basin (South Dakota)}

[Note: The following discussion on the James River basin is taken directly from the State of South Dakota's 1998 305(b) Water Quality Assessment Report.]

Water quality in the James River basin has shown steady improvement over the past 10 years. Better water quality may have resulted in a large part due to completed and ongoing projects for construction and rehabilitation of wastewater treatment facilities for small municipalities and the City of Huron. Completion of an upgrade of the Huron wastewater facility should prevent further emergency discharges which in the past have been responsible for fish kills in the James River. However, river turbidity (cloudy or muddy water) may remain a persistent problem in the James River due to the considerable silt and sediment periodically brought in by its many small tributaries and the large amount of previously accumulated material on the river bottom.

Most of the lower James River basin fully supported its beneficial uses during the assessment period of 1992-97. Moderate impairment was caused by elevated total suspended solids (TSS) in the lowest reach. Minor impacts over the entire lower half of the river course were mainly elevated TSS, fecal coliform, total dissolved solids, $\mathrm{pH}$, and low dissolved oxygen. Oxygen levels in the lower river appeared to have improved since previous assessments whereas instances of elevated TSS (>90 mg/l) increased in 1993 and were particularly high from 1993 to 1995 . More rainfall and greater river flows in the area may have further increased stream turbidity at that time.

\subsubsection{Vermillion River Basin}

[Note: The following discussion on the Vermillion River basin is taken directly form the State of South Dakota's 1998 305(b) Water Quality Assessment Report.]

The water quality in the Vermillion River basin is usually marginal for the designated beneficial uses - most often the result of elevated total suspended solids (TSS). During the previous two reporting periods (1991-1995) the warmwater fishery use continued to be impacted by excessive TSS which represented the sole cause of non-support for the entire drainage. Moderate increases in TSS were noted during 1995-1997 which was a similarly wet period in 
the watershed. Total dissolved solids showed a moderate decline although there was little change in water $\mathrm{pH}$ between reporting cycles. A moderate impairment for secondary contact was noted in the upper and lower reach of the river due to elevated fecal coliform numbers.

Overall water quality in the basin has remained relatively stable since 1986 with moderate fluctuations in TSS during most years and a decline in fecal coliform concentrations from the levels reported in 1986. The present evaluation of the lower quarter of the river course covered 5.75 years of accumulated data and resulted in a rating of non-support due to excessive TSS and moderate impairment owing to elevated fecal coliform bacteria concentrations.

\section{METHODS}

\subsection{MONITORING LOCATIONS AND SAMPLING SITES}

\subsubsection{Location of Monitoring Sites Along the MNRR Reach}

A total of nine monitoring locations were established on the Missouri, James, and Vermillion Rivers as part of the scoping study (Plate 3). Location 1 was on the Missouri River approximately 1 mile below Gavins point Dam at Missouri River Mile (RM) 810 and consisted of a thalweg site only (Plate 4). Location 2 was on the Missouri River, approximately 0.5 miles above the confluence of the James River at RM 801, and had both a thalweg and backwater site (Plate 5). Location 3 was on the James River approximately 0.5 miles upstream from the Missouri River, and water quality samples were collected at a single mid-channel site (Plate 5). Location 3T was located on a side channel of the Missouri River that received the inflow of the James River, and four sites (3T1, 3T2, 3T3, and 3T4) were sampled along an approximate 2 mile distance of the side channel downstream from the mouth of the James River (Plate 5). Location 4 was on the Missouri River, approximately 1 mile below where the side channel receiving the James River flow enters the main channel flow of the Missouri River at RM 797, and consisted of both a thalweg and backwater site (Plate 5). Location 5 was on the Missouri River approximately 1 mile upstream from the confluence of the Vermillion River at RM 774, and consisted of both a thalweg and backwater site (Plate 6). Location 6 was on the Vermillion River approximately 0.5 miles upstream of its confluence with the Missouri River and water quality samples were collected at a single mid-channel site (Plate 6). Location 7 was on the Missouri River, approximately 0.5 miles below the confluence of the Vermillion River at RM 771, and consisted of both a thalweg and backwater site (Plate 6). Location 8 was on the Missouri River at Ponca State Park, Nebraska at RM 753 and consisted of both a thalweg and backwater site (Plate 7).

\subsubsection{Sampling Sites}

Sampling sites consisted of four types: 1) thalweg, 2) backwater, 3) special turbidity, and 4) tributary. Thalweg sites were defined as locations on the Missouri River where the current was fast $(>2 \mathrm{ft} / \mathrm{sec}$ ) and the water was deep ( $>5 \mathrm{ft}$ ). Thalweg sites were sampled at all Missouri River monitoring locations (i.e., Locations 1, 2, 4, 5, 7 and 8). Backwater sites were defined as locations on the Missouri River where the current was slow ( $<2 \mathrm{ft} / \mathrm{sec})$ and the water was shallow ( $<5 \mathrm{ft}$ ). Backwater sites were sampled at all Missouri River locations except Location 1 (i.e., Locations 2, 4, 5, 7, and 8); no extensive backwater conditions existed at Location 1. Special turbidity sites were established on a side channel of the Missouri River into which the James River discharges (i.e., Locations 3T1, 3T2, 3T3, and 3T4). These sites were 
established to further evaluate the effects of the James River on turbidity levels in the Missouri River. Tributary sites were located on the James and Vermillion Rivers (i.e., Locations 3 and 6).

\subsection{DETERMINATION OF WATER QUALITY CONDITIONS}

\subsubsection{Field Measurements}

Field measurements were obtained using a Hydrolab, Secchi disc, and GPS receiver. A Hydrolab DataSonde 4 was used to take measurements of water quality conditions within onemeter of the surface at all monitoring locations. The water quality conditions measured were water temperature, dissolved oxygen, $\mathrm{pH}$, and conductivity. A Secchi disc was used to measure visual water clarity. A black-and-white Secchi disc was bolted to the end of a pole with a tape measure attached. The pole was used to maintain the Secchi disc parallel to the water surface in the current. The Secchi disc was lowered into the water until the image was judged to just disappear from view. This depth, in inches, was determined from the tape measure and recorded as the Secchi depth. Geo-locational data were obtained at each site when a water quality sample was collected. A Garmin, GPSmap 76, hand-held GPS receiver was used to obtain geo-positional data. This GPS unit has a minimum accuracy of 15 meters. All field measurement were taken weekly during the six-week sampling period.

\subsubsection{Sample Collection}

All water samples for laboratory analysis were collected from a boat anchored at the site being sampled. Near-surface and near-bottom water quality samples were collected weekly at the appropriate sampling sites.

\subsubsection{Near-Surface Samples}

Near-surface water quality samples were collected at all the monitoring locations and sampling sites (i.e., 1T, 2B, 2T, 3, 3T1, 3T2, 3T3, 3T4, 4B, 4T, 5B, 5T, 6, 7B, 7T, 8B, and 8T). Near-surface water samples were collected by dipping a plastic bucket, equipped with a churn, below the water surface and filling the bucket. The bucket was rinsed with site water prior to collecting the sample. Two plastic one-liter bottles were filled from the bucket as it was churned. One bottle was preserved with $5 \mathrm{ml}$ of concentrated sulfuric acid and the other was left unpreserved. When herbicides were to be analyzed a third one-quart glass, amber bottle was also filled.

\subsubsection{Near-Bottom Samples}

Near-bottom water samples were collected at all the thalweg sampling sites (i.e., 1T, 2T, 4T, 5T, 7T, and 8T). Near-bottom water samples were collected by lowering a weighted Kermmerer sampler to the bottom and triggering the device. The triggered sampler was retrieved to the surface and the contents emptied into the plastic bucket equipped with a churn. A single one-liter plastic bottle was filled from the bucket as it was churned.

\subsubsection{Laboratory Analysis and Sample Preservation}

The collected water samples were delivered to the Corps Waterways Experiment Station (WES) laboratory in Omaha, Nebraska for analysis within 24 hours of their collection. Laboratory analysis of the samples consisted of turbidity; total suspended solids, total organic carbon, total phosphorus, total Kjeldahl nitrogen, total ammonia, nitrate/nitrite nitrogen, 
chlorophyll a, atrazine, alachlor, and metolachlor. Table 2 gives the method, method detection limit, and reporting limit for each of the parameters analyzed. Values greater than the method detection limit and less the reporting limit were qualified as estimated values. Near-surface thalweg and tributary samples were analyzed for all of the above parameters with the exception that the three herbicides (alachlor, atrazine, and metolachlor) were analyzed for every other week. Near-bottom thalweg samples were analyzed for turbidity and suspended solids. Backwater samples were analyzed for turbidity, suspended solids, and chlorophyll a. Special turbidity sites were analyzed for turbidity only. Samples for nutrient analyses were preserved with $5 \mathrm{ml}$ of concentrated sulfuric acid when collected. All samples were placed on ice as soon as possible after collection.

\subsection{FLOW ESTIMATION}

Accounting for discharge is a primary consideration in any riverine water quality study. Generally, a great deal of the variance in water quality variables in a riverine setting is a function of discharge. This is a result of two different kinds of physical phenomena: dilution and wash off (Hirsch et. al, 1991). If a constituent is being delivered to a river or stream at a reasonably consistent rate (e.g., a point source or ground water discharge), as river flows increase these constituents will tend to be diluted and their concentrations reduced. Wash off from the watershed due to overland flow and streambank erosion can transport a solute, sediment, or a constituent attached to sediment into a river or stream. Under these runoff situations, the concentrations of nonpoint source pollutants tend to rise with increasing discharge. When the flow in a river or stream is regulated by dam releases, water quality in the river below will be highly dependent upon the water quality in the reservoir behind the dam and the discharge rate. Water quality conditions in a regulated river can be a reflection of all of these situations occurring at the same time. Knowing river flows when water quality constituents are measured can go a long way in helping to explain the variability in water quality conditions.

Flows through the MNRR reach were estimated from existing stream gaging stations. Plate 8 shows the location and type of permanent flow gaging stations on the MNRR reach and on tributaries in close proximity to the reach. Mean daily discharge values for the period August 17 through September 26, 2001 were calculated for the five gages capable of recording discharge (i.e., Gavins Point Dam, Scotland Gage, Vermillion Gage, Akron Gage, and Sioux City Gage). Flow in the Missouri River from Gavins Point Dam down to the James River was defined as the discharge from Gavins Point Dam. Flow in the Missouri River from the James River to the Vermillion River was defined as the discharge from Gavins Point Dam plus the flow measured in the James River at the Scotland gage. Flow in the Missouri River below the Vermillion River was taken to be the discharge from Gavins Point Dam plus the James River flow measured at the Scotland gage plus the Vermillion River flow measured at the Vermillion gage. This process discounted the flows contributed to the James and Vermillion Rivers below the Scotland and Vermillion gage sites and the flow contributed by the other tributaries discharging directly to the Missouri River. It is noted that the flow at the downstream boundary of the MNRR reach could also be estimated as the flow recorded at the Sioux City gage minus the flow recorded at the Akron gage. This discounts flow contributed to the Big Sioux River below the Akron gage and flow contributed by tributaries discharging to the Missouri River downstream from the lower boundary of the MNRR reach (e.g., Aowa Creek in Nebraska). Table 3 gives the mean daily discharge values for the five gages determined for the period August 17 through September 26, 2001.

To verify flows through the MNRR reach, a water balance was constructed that compared the estimated flow at the end of the MNRR reach as determined by the addition of the 
upstream gages (i.e., Gavins Point Dam, Scotland gage, and Vermillion gage) and as determined by the subtraction of the Akron gage from the Sioux City gage. Table 4 gives the estimated mean daily flows out of the MNRR reach based on these two methods. The average daily flow for the period of August 17 through September 26 determined by adding the upstream gages was 27,565 cfs, while the average daily flow determined from the downstream gages was 27,985 cfs; a difference of $420 \mathrm{cfs}(1.52 \%)$. The relative percent difference (RPD) between the same day mean daily flows determined from the two methods was calculated (Table 4). The mean RPD value based on 41 pairings was $2.16 \%$. It is noted that the Corps has determined the channel velocity of the Missouri River through the MNRR reach ranges from about 2 to 5 $\mathrm{ft} / \mathrm{sec}$. Using an average velocity of $3.5 \mathrm{ft} / \mathrm{sec}(2.4 \mathrm{mph})$ an estimated time-of-travel through the 57-mile reach would be about 24 hours. Based on the estimated time-of travel, RPD values were also determined by pairing a 1-day delay in the downstream estimate (i.e., the downstream estimate was paired with the previous day upstream estimate). This resulted in a mean RPD value based on 40 pairings of $1.60 \%$. The RPD values indicate that the two estimation methods yielded very similar results - the addition of the upstream gages (i.e., Gavins Point Dam, Scotland, and Vermillion) account for about $98 \%$ of the flow occurring through the MNRR reach as estimated by the downstream gages.

\subsection{AsSessment OF WATER Quality DATA}

The water quality data collected during the scoping study were assessed in the following ways: 1) descriptive statistics (i.e., mean, median, minimum, and maximum) were calculated for all measured parameters, 2) box plots were constructed to visually display the distribution of the measurements for each parameter, and 3) a simple two-tailed, paired t-test was used to test for significant differences between selected monitoring locations and sampling sites. It was assumed that the collected data met the requirements for application of parametric statistics (i.e., normality, homogenous variance, and independence of observations). This assumption was believed valid since no major runoff events occurred during the scoping period. Episodic runoff events tend to skew water quality data and cause the assumptions for use of parametric statistics to be violated. It is also noted that the calculated mean and median values for most measured parameters were quite similar (Table 5).

\subsection{DATA QUALITY INDICATORS}

Quality assurance/quality control (QA/QC) samples, a field blank and duplicate, were created on each sampling trip to evaluate the quality of the data generated by the scoping study. These QA/QC samples were in addition to the internal QA/QC samples utilized by the WES Laboratory as part of the Laboratory's QA/QC program. The six field blank samples were used to generate a data quality indicator for accuracy. De-ionized water was used to fill a set of sample containers at a random monitoring location. The field blanks were handled identically as the site samples. The measurement quality objective that was established for accuracy was that the field blanks should be below detection limits for all parameters analyzed for in the laboratory. The six collocated field duplicate samples were used to generate a data quality indicator for precision. A collocated sample was collected at random from a near-surface thalweg sampling site on each of the six sampling trips. The measurement quality objective established for precision was that the collocated samples should not deviate by more than $25 \%$, as measured by their relative percent difference. 


\section{RESULTS AND DISCUSSION}

\subsection{General WATER QUALITY Conditions}

A statistical summary of the water quality conditions monitored at the surface thalweg and tributary sites during the scoping study is given in Table 5. Monitored dissolved oxygen, $\mathrm{pH}$, and total ammonia values were supportive of state water quality standards at all times. Of the three herbicides measures, only atrazine was present in levels above the detection limit of $0.05 \mu \mathrm{g} / \mathrm{l}$. The only site where the measured atrazine levels were above the reporting limit of $0.1 \mu \mathrm{g} / \mathrm{l}$ was Site 6 (i.e., Vermillion River) where the measured values ranged from 0.07 to 0.28 $\mu \mathrm{g} / \mathrm{l}$. Measured conductivity, turbidity, total organic carbon, total phosphorus, and total kjeldahl nitrogen levels were noticeable higher and the measured secchi depths noticeable lower at the tributary sites on the James and Vermillion Rivers. All measured total suspended solids concentrations were at or below $100 \mathrm{mg} / \mathrm{l}$ and all measured nitrate-nitrite nitrogen concentrations were below $0.2 \mathrm{mg} / \mathrm{l}$. Chlorophyll a concentrations were highly variable at all sites.

\subsection{LONGITUDINAL VARIATION IN WATER QUALITY}

Longitudinal variation in water quality through the MNRR reach was evaluated by assessing the water quality conditions monitored at "completely-mixed" near-surface thalweg sampling sites. Of the six near-surface thalweg monitoring sites along the Missouri River (i.e., Sites 1Ts, 2Ts, 4Ts, 5Ts, 7Ts, and 8Ts), two sites, 4Ts and 7Ts, did not represent completelymixed conditions. Site 4Ts, although located below the mouth of the James River, did not represent water quality conditions in the Missouri River resulting from complete mixing of the James River inflow. The James River flows into the Missouri River from the north and enters a side channel of the Missouri River that is separated from the main channel of the river by a large island. Site 4Ts was located near the south bank of the Missouri River just downstream from the large island and was above the "plume" formed in the Missouri River from the James River inflow. Site 4Ts represented conditions very similar to Site 2Ts. Site 7Ts was located approximately one-half mile downstream from the mouth of the Vermillion River. The Vermillion River enters the Missouri River from the north and Site 7Ts was near the north bank of the Missouri River. In reviewing the water quality results it was determined that Site 7Ts did not represent the conditions of the Vermillion River inflow being completely-mixed with the Missouri River. Based on conductivity measurements, a slight plume of "Vermillion River water" was still noticeable at Site 7Ts. Longitudinal variation in water quality along the MNRR reach was assessed by comparing conditions at Sites 1Ts, 2Ts, 5Ts, and 8Ts.

Monitoring results were used to construct box plots for each parameter measured, except alachlor and metolachlor, at Sites 1Ts, 2Ts, 5Ts, and 8Ts during the scoping study. As noted previously, all samples analyzed for alachlor and metolachlor were below method detection limits. The constructed parameter box plots were plotted, by site, on a graph where the x-axis represented Missouri River mileage points (Plate 9). Based on this graphical representation it was determined that water temperature, $\mathrm{pH}$, total organic carbon, total Kjeldahl nitrogen, total ammonia, nitrate-nitrite, chlorophyll $a$, and atrazine exhibited no noticeable longitudinal variation through the MNRR reach; while, dissolved oxygen, conductivity, Secchi depth, turbidity, total suspended solids, and total phosphorus did. For the six parameters that exhibited longitudinal variation it was concluded that no noticeable difference existed between Sites 1Ts and 2Ts; however, there was a noticeable difference between Sites 2Ts and 5Ts for all six parameters and Sites 5Ts and 8Ts for all the parameters except conductivity. Statistical assessment (two-tailed, paired t-test) of the measured values obtained at Sites 2Ts and 5Ts 
where there was a noticeable difference observed in Plate 9, found the following significance levels (rounded to two significant digits): conductivity $(p=0.02)$, dissolved oxygen $(p=0.05)$, Secchi depth $(p=0.03)$, turbidity $(p<0.01)$, total suspended solids $(p<0.01)$, and total phosphorus $(p<0.01)$. A similar assessment of the measured values obtained at Sites 5Ts and 8Ts found the following significance levels: dissolved oxygen $(p=0.04)$, Secchi depth $(p=$ $0.05)$, turbidity $(p=0.02)$, total suspended solids $(p=0.01)$, and total phosphorus $(p<0.01)$.

The differences between Sites 2Ts and 5Ts and Sites 5Ts and 8Ts for all the noted parameters except possibly dissolved oxygen are believed due to the respective inflows of the James and Vermillion Rivers. The differences in dissolved oxygen may be due to other factors. It is noted that the Sites 1Ts and 2 Ts were sampled in the early morning, Site 5 Ts was sampled around noon, and Site 8Ts was sampled in the late afternoon. The dissolved oxygen percent saturation levels measured at Sites 1Ts and 2Ts were in the low 90's, at Site 5Ts it was in the high 90's, and at Site 8Ts it was above 100\%. This downstream pattern of increasing dissolved oxygen concentrations and percent saturations could be reflective of the "normal" diurnal changes in dissolved oxygen due to photosynthesis and respiration. It is also noted that the pattern could be the result of reoxygenation of lower oxygenated water discharged from the reservoir through Gavins Point Dam or a possible bias introduced into the measurements from meter drift.

\subsection{LOCALIZED VARIATION IN WATER QUALITY}

\subsubsection{Near-Surface Versus Near-Bottom Thalweg Sites}

Near-surface and near-bottom thalweg turbidity and total suspended solids levels were compared for each of the Missouri River monitoring locations (i.e., Locations 1, 2, 4, 5, 7, and 8). Side-by-side box plots of the near-surface and near-bottom samples for turbidity and total suspended solids are shown in Plates 10 through 15. A statistical assessment (two-tailed, paired t-test) of the turbidity results revealed that no significant difference $(\alpha=0.10)$ existed between the near-surface and near-bottom sites at any of the six assessed monitoring locations. Significant differences $(\alpha=0.10)$ in suspended solids levels did exist between the near-surface and near-bottom samples at monitoring locations $1(p=0.08), 2(p=0.04)$, and $7(p=0.08)$-- in all cases, the total suspended solids concentrations were higher in the near-bottom samples (Plates 10, 11, and 14). The higher suspended solids levels in the near-bottom samples were attributed to the "bed load" material being transported near the bottom of the river. However, the magnitude of the difference between the near-surface and near-bottom suspended solids levels was small, and it did not result in significantly different turbidity levels.

\subsubsection{Thalweg Versus Backwater Sites}

Measured turbidity, total suspended solids, and chlorophyll a levels were compared for near-surface thalweg and backwater samples collected at monitoring locations 2, 4, 5, 7, and 8. Side-by-side box plots displaying the distribution of the measured levels at the five monitoring locations is presented in Plates 11 through 15. The statistical assessment (two-tailed, paired ttest) of the chlorophyll a results revealed that no significant difference $(\alpha=0.20)$ existed between the backwater and near-surface thalweg sites at any of the five monitoring locations. Significant differences $(\alpha=0.05)$ in the turbidity and total suspended solids levels existed between the backwater and near-surface thalweg sites at monitoring locations 4 and 7 . The significant difference between the backwater and near-surface thalweg sites at monitoring location 4 is attributed to the effects of the James River inflow. The backwater site at this 
location, which was in the plume formed below the James River inflow, had higher turbidity and total suspended levels than the near-surface thalweg site that was above the plume (Plate 12). The significant difference between the two sites at monitoring location 7 is believed due to the influence of the Vermillion River inflow. The near-surface thalweg site at this location, which was in the plume formed below the Vermillion River inflow, had higher turbidity and suspended solids levels than the backwater site that was above the plume (Plate 14). The only significant difference between the backwater and near-surface thalweg sites at monitoring locations 5 and 8 , which represented completely-mixed conditions, was the difference in turbidity levels $(\alpha=$ 0.05) at monitoring location 5. Turbidity levels were higher at the backwater site, but the magnitude of the difference was quite small (Plate 13).

\subsection{Effects Of The James And Vermillion Rivers On TuRbidity In The Missouri River}

The inflow of the James River appears to have a significant influence on turbidity levels in the Missouri River (Plate 9). During the scoping study a turbidity plume was observed below the mouth of the James River in the side channel of the Missouri River into which it enters. This turbidity plume can visually be seen in the 1997 orthophoto of the area (Plate 16). Mean turbidity, Secchi depth, and conductivity values calculated from the data collected at Sites 2Ts, $3,3 T 1,3 T 2,3 T 3,3 T 4,4 B$ and 5Ts are given in Table 6. The plume formed below the James River stays relatively intact throughout the entire length of the side-channel of the Missouri River into which it flows. As seen in the data collected at Site 4B, the plume still exists within the Missouri River one-half mile below where the side-channel rejoins the main river, but is dissipating (Table 6).

Based on the average of the estimated mean daily flows for Sites 2Ts (26,286 cfs) and 3 $(1,144 \mathrm{cfs})$ the dilution factor of the Missouri River to the James River inflow is approximately 23:1. This dilution factor was used to project when the James River inflow would be completelymixed with the Missouri River based on conductivity levels. The mean conductivity levels measured at Sites 2 Ts and 3 were respectively 833 and 1,256 $\mu$ mhos (Table 6). Applying a 23:1 dilution factor to these mean values, a completely-mixed situation would be present when conductivity levels in the Missouri River reached approximately $851 \mu$ mhos. The mean conductivity determined for Site 5 Ts was $853 \mu$ mhos (Table 6). It was therefore concluded that the James River inflow has completely-mixed with the Missouri River by the time the flows have reached Site 5Ts, which is approximately 28 river miles downstream from the mouth of the James River.

It is noted that the turbidity levels measured at Sites 2 Ts, 3, and 5 Ts do not conform to the 23:1 dilution factor, as does conductivity. This can possibly be attributed to two factors. First, conductivity is a "quantitative measurement" of a physicochemical property of water that conforms to a simple dilution analysis. Turbidity, on the other hand, is a "relative measurement" of an optical property of the water (i.e., "cloudiness" of water caused by the light scattering of suspended particles). The important attributes of suspended particles regarding their optical character and other important aspects of environmental behavior, notably settling velocity, are their particle size, shape and composition (Davies-Colley and Smith, 2001). Thus simple dilution is a lesser factor in determining turbidity levels than the particle size, shape, and composition of the suspended material. Second, streambed degradation and streambank erosion may be contributing to turbidity levels as the river flows downstream between the sites.

Turbidity levels significantly increased between the two sites, 5Ts and 8Ts, where the Vermillion River enters the Missouri River (Plate 9). Mean turbidity, Secchi depth, and 
conductivity values calculated from the data collected at Sites 5Ts, 6, 7Ts, and 8Ts are given in Table 6. As seen in the mean conductivity value for Site 7Ts, a limited plume did occur below the inflow of the Vermillion River. Site 7Ts was located approximately one-half mile downstream from the mouth of the Vermillion River near the north bank (Plate 6).

Based on the average of the estimated mean daily flows for Sites 5Ts (27,430 cfs) and 6 (135 cfs) the dilution factor of the Missouri River to the Vermillion River inflow is approximately 203:1. This dilution factor was used to project when the Vermillion River inflow would be completely-mixed with the Missouri River based on conductivity levels. The mean conductivity levels measured at Sites 5Ts and 6 were respectively 853 and 1,385 $\mu$ mhos (Table 6). Applying a 203:1 dilution factor to these mean values, a completely-mixed situation would be present when conductivity levels in the Missouri River reached approximately $856 \mu$ mhos. The mean conductivity determined for Sites 7Ts and 8Ts was, respectively, 864 and $851 \mu$ mhos (Table 6). It was therefore concluded that the Vermillion River inflow has completely-mixed with the Missouri River by the time the flows have reached Site 8Ts, which is approximately 19 river miles downstream from the mouth of the Vermillion River.

As was seen in conditions above and below the James River, the mean turbidity levels above and below the Vermillion River (Sites 5Ts and 8Ts) do not conform to a simple dilution analysis, as does conductivity. However, the magnitude of the nonconformity below the Vermillion River is much more apparent given the dilution factor of 203:1. Streambed degradation and streambank erosion may be influencing turbidity levels to a greater degree in the reach between Sites 5Ts and 8Ts.

The daily load of total suspended solids (TSS) delivered by the inflows of the James and Vermillion Rivers was estimated for each of the days (TSS) was measured. The estimate was based on the average daily flows recorded at the Scotland and Vermillion gages and the total suspended solids concentration measured on that day. Table 7 gives the daily total suspended solids loads estimated for each of the 6 days water quality samples were collected during the scoping study. The average daily load of total suspended solids delivered by the James and Vermillion Rivers was estimated to be, respectively, 169.8 and 14.5 tons.

\subsection{DATA QUALITY INDICATORS}

\subsubsection{Accuracy}

A review of the analysis results obtained for the six field blank samples found only one occurrence of a reported value greater than a detection limit. The one occurrence was an estimated value of $2 \mu \mathrm{g} / \mathrm{l}$ for chlorophyll $a$. The detection limit for chlorophyll $a$ is $1 \mu \mathrm{g} / \mathrm{l}$ and the reporting limit is $3 \mu \mathrm{g} / \mathrm{l}$. Given that this one occurrence was an estimated value near the detection limit, it was not considered significant.

\subsubsection{Precision}

Table 8 gives the analytical results of the collocated samples and the relative percent difference (RPD) for the analyzed parameter. The RPD was calculated only when the analytical results for a parameter were above the reporting limit. Of the total 36 RPD values calculated for all parameters, 4 were at or above $25 \%$. Two of the 4 RPD values calculated for chlorophyll a were at or above $25 \%$, while 1 of 6 were for total phosphorus and turbidity. The RPD values calculated for the 4 chlorophyll a paired samples ranged from 10.5 to $93.3 \%$, and raise a 
concern on the precision of the chlorophyll a results. It is noted that the 8 reported chlorophyll a values were relatively low (i.e., all less than $15 \mu \mathrm{g} / \mathrm{l}$ ). From a water quality standpoint these are low values, and although poor precision is a concern, it is not considered environmentally significant. The reported turbidity values for one pair of collocated samples were 39 and 19 NTUs (RPD $=69.0 \%$ ). The other 5 paired turbidity values were within 2 NTUs of each other (RPD values of $0.0,0.0,4.7,4.9$, and 10.0). Although the RPD of the one pair of turbidity measurements is a concern, the overall precision of the turbidity measurements for the scoping study is considered good based on the other 5 collocated samples. The one high RPD value may represent an outlier situation. The one RPD value for total phosphorus above $25 \%$ was $28.6 \%$, and resulted from paired values of 0.04 and $0.03 \mathrm{mg} / \mathrm{l}$. These values are near the detection and reporting limit for total phosphorus and are very low from a water quality standpoint. The "high" RPD value is a reflection of the low magnitude of the paired results and is not considered significant. Overall, the precision of the analyzed parameters is considered good, with some concern regarding the measured chlorophyll a values.

\section{SUMMARY}

The overall water quality of the MNRR reach appears to be good. All the water quality parameters monitored in the MNRR reach during the scoping study met the appropriate state water quality standards adopted pursuant to the Federal Clean Water Act. Significant longitudinal variation through the reach was observed for the monitored parameters of conductivity, dissolved oxygen, Secchi depth, turbidity, total suspended solids, and total phosphorus. The longitudinal variation of all these parameters except dissolved oxygen, appears to be largely attributed to the inflows of the James and Vermillion Rivers. Little difference was observed between near-surface and near-bottom thalweg water quality conditions and near-surface thalweg and backwater water quality conditions. It is noted that these observations are based on a limited sampling period (i.e., late August through September) of a single year and are probably seasonally biased.

\section{RECOMMENDATIONS}

\subsection{AdDITIONAL WATER QUALITY MONITORING}

It is recommended that the ODWQU implement a 2 to 3 year monitoring project to define the water quality conditions that exist in the MNRR reach. The scoping study established that there is longitudinal variation in water quality along the MNRR reach, and it appears that the inflows of the James and Vermillion Rivers play a significant role in this variation. The scoping study was limited in its temporal coverage and additional monitoring is needed to account for seasonal variation in water quality. The monitoring project should include near-surface thalweg sampling at 3 Missouri River sites (immediately below Gavins Point Dam, near Maskell, NE, and at Ponca State Park, NE). These sampling points along the Missouri River will represent completely-mixed conditions that bracket the inflows of the James and Vermillion Rivers. Two additional sites, one on the James River and one on the Vermillion River near their mouths, should also be collected. The sampling sites on the James and Vermillion Rivers could be at the South Dakota state highway 50 bridge crossings. Ongoing South Dakota Department of Natural Resources water quality monitoring activities on the James and Vermillion Rivers should be reviewed for possible partnering and data-sharing opportunities. The recommended sampling period is April through October. During this sampling period it is recommended that systematic monthly grab samples be collected. In addition to the systematic monthly samples, 4 additional spring season grab samples and up to 4 additional runoff grab samples should be collected. Parameters coverage should include field measurements of water temperature, 
dissolved oxygen, conductivity, $\mathrm{pH}$, and turbidity; and analytical measurements of nutrients, suspended solids, selected herbicides and priority pollutants. The Nebraska Department of Environmental Quality should be consulted as to the parameters they deemed important regarding implementation of their Tier 3 antidegradation provisions.

\subsection{WATER QUALITY MANAGEMENT CONCERNS}

A water quality management concern is the seemingly contradictory water quality management goals identified for the MNRR reach under the Federal Endangered Species Act (ESA), Clean Water Act (CWA), and Wild and Scenic Rivers Act (WSRA). The BiOp, developed pursuant to the ESA, directs the Corps to increase turbidity and suspended solids in the MNRR. The BiOp states that sediment transport and turbidity need to be restored to functional levels in the MNRR reach to improve habitat conditions for the jeopardized species inhabiting the reach. State water quality standards (i.e., South Dakota and Nebraska) adopted pursuant to the CWA require that suspended solids and turbidity levels be maintained at "reduced" levels in the MNRR reach, and imply that increasing turbidity and suspended solids levels in the reach could represent a degradation of water quality conditions and a possible impairment of a designated beneficial use. South Dakota has specifically adopted water quality standards criteria to manage total suspended solids levels in the MNRR reach. One of the beneficial uses South Dakota designates on the MNRR reach is "warmwater permanent fish life propagation". Protection of this use requires that total suspended solids levels are to be $\leq 158 \mathrm{mg} / \mathrm{l}$ as a daily maximum, and $\leq 90 \mathrm{mg} / \mathrm{l}$ as a 30-day average. Management of the MNRR reach as a recreational river under the WSRA requires that the values for which it was designated as a recreational river (i.e., its outstanding remarkable recreational, fish and wildlife, aesthetic, historical, and cultural values) be protected and enhanced. Increasing suspended solids and turbidity levels in the MNRR reach may degrade the habitat for recreationally important fish species that were present in the reach when it was designated as a recreational river. The existing water quality literature suggests that elevated levels of turbidity adversely impact the recreational and aesthetic values of a waterbody. The U.S. Environmental Protection Agency's "Red Book" states; "Turbid water interferes with recreational use and aesthetic enjoyment of water" (USEPA, 1976). The USFWS should enter consultation with EPA Regions VII and VIII, and possibly the NPS, to discuss coordinating the water quality aspects of the BiOp, CWA, and WSRA to ensure that there are consistent water quality management goals on the MNRR reach. 


\section{REFERENCES}

Bailey, R.M., and F.B. Cross. 1954. River sturgeons of the American genus Scaphirhynchus: characters, distribution, and synonymy. Papers of the Michigan Academy of Science, Arts, and Letters 39: 169-208.

Davies-Colley, R.J. and, D.G. Smith. 2001. Turbidity, suspended sediment, and water clarity: a review. J. Amer. Water Resources Association, Vol. 37, No. 5, pgs 1085-1101.

Erickson, J.D. 1992. Habitat selection and movement of pallid sturgeon in Lake Sharpe, South Dakota. M.S. Thesis, South Dakota State University, Brookings, SD.

Hirsch, R.M., R.B. Alexander, and R.A. Smith. 1991. Selection of methods for the detection and estimation of trends in water quality. Water Resources Research, Vol. 27, No. 5, pgs $803-813$.

Nebraska Department of Environmental Quality. 2000. Title 117 - Nebraska surface water quality standards. Revised Effective Date: February 7, 2000. Nebraska Department of Environmental Quality. Lincoln, Nebraska.

South Dakota Department of Environment and Natural Resources. 1998. The 1998 South Dakota Report to Congress - 305(b) Water Quality Assessment. South Dakota Department of Environment and Natural Resources. Pierre, South Dakota.

U.S. Environmental Protection Agency. 1976. Quality criteria for water - "Red Book". U.S. Environmental Protection Agency, Washington, DC.

. 1994. Water Quality Standards Handbook - Second Edition. Water Quality Standards Branch, Office of Science and Technology, U.S. Environmental Protection Agency, Washington, DC.

U.S. Fish and Wildlife Service. 1993. Pallid sturgeon recovery plan. U.S. Fish and Wildlife Service, Bismarck, North Dakota. 55pp.

. 2000. Biological Opinion on the Operation of the Missouri River Main Stem Reservoir System, Operation and Maintenance of the Missouri River Bank Stabilization and navigation Project, and Operation of the Kansas River Reservoir System. U.S. Fish and Wildlife Service, Region 6, Denver, Colorado, Region 3, Fort Snelling, Minnesota. 
Table 1. 8-Digit Hydrologic Units (HUCs) that make up the watershed, below Gavins Point Dam, of the MNRR Reach.

\begin{tabular}{|c|l|r|}
\hline \hline HUC Number & \multicolumn{1}{|c|}{ HUC Name } & $\begin{array}{c}\text { Approximate Area } \\
\text { (sq. miles) }\end{array}$ \\
\hline 10160001 & James River Headwaters & 1760 \\
10160002 & Pipestem Reservoir & 1040 \\
10160003 & Upper James River & 4250 \\
10160004 & Elm Creek & 1600 \\
10160005 & Mud Creek & 650 \\
10160006 & Middle James River & 3640 \\
10160007 & East Missouri Coteau & 890 \\
10160008 & Snake Creek & 1520 \\
10160009 & Turtle Creek & 1480 \\
10160010 & North Big Sioux Coteau & 1230 \\
10160011 & Lower James & 3530 \\
10170101 & Lewis and Clark Lake* & 3240 \\
10170102 & Vermillion River & 2240 \\
10170103 & South Big Sioux Coteau & 410 \\
\hline $10170101^{*}$ & (MNRR Reach) & 880 \\
$10170101^{*}$ & (Above and Below MNRR Reach) & 2360 \\
\hline
\end{tabular}

Table 2. Analytical method, method detection limit, and reporting limit for parameters analyzed in the WES Laboratory.

\begin{tabular}{|l|c|c|c|}
\hline \hline \multicolumn{1}{|c|}{ Parameter } & Analytical Method & Method Detection Limit & Reporting Limit \\
\hline Turbidity $(\mathrm{NTU})$ & EPA180.1 & $1 \mathrm{NTU}$ & $3 \mathrm{NTU}$ \\
\hline Total Suspended Solids $(\mathrm{mg} / \mathrm{l})$ & EPA160.2 & $4 \mathrm{mg} / \mathrm{l}$ & $10 \mathrm{mg} / \mathrm{l}$ \\
\hline Total Organic Carbon $(\mathrm{mg} / \mathrm{l})$ & EPA9060 & $0.05 \mathrm{mg} / \mathrm{l}$ & $0.25 \mathrm{mg} / \mathrm{l}$ \\
\hline Total Phosphorus $(\mathrm{mg} / \mathrm{l})$ & EPA365.4 & $0.01 \mathrm{mg} / \mathrm{l}$ & $0.02 \mathrm{mg} / \mathrm{l}$ \\
\hline Total Kjeldahl Nitrogen $(\mathrm{mg} / \mathrm{l})$ & EPA351.2 & $0.1 \mathrm{mg} / \mathrm{l}$ & $0.2 \mathrm{mg} / \mathrm{l}$ \\
\hline Total Ammonia $(\mathrm{mg} / \mathrm{l})$ & EPA350.1 & $0.01 \mathrm{mg} / \mathrm{l}$ & $0.1 \mathrm{mg} / \mathrm{l}$ \\
\hline Nitrate/Nitrate as N $(\mathrm{mg} / \mathrm{l})$ & EPA353.2 & $0.02 \mathrm{mg} / \mathrm{l}$ & $0.1 \mathrm{mg} / \mathrm{l}$ \\
\hline Chlorphyll $a(\mu \mathrm{g} / \mathrm{l})$ & SM10200H2 & $1 \mu \mathrm{g} / \mathrm{l}$ & $3 \mu \mathrm{g} / \mathrm{l}$ \\
\hline Atrazine $(\mu \mathrm{g} / \mathrm{l})$ & EPA507 & $0.05 \mu \mathrm{g} / \mathrm{l}$ & $0.1 \mu \mathrm{g} / \mathrm{l}$ \\
\hline Alachlor $(\mu \mathrm{g} / \mathrm{l})$ & EPA507 & $0.05 \mu \mathrm{g} / \mathrm{l}$ & $0.1 \mu \mathrm{g} / \mathrm{l}$ \\
\hline Metholachlor $(\mu \mathrm{g} / \mathrm{l})$ & EPA507 & $0.05 \mu \mathrm{g} / \mathrm{l}$ & $0.1 \mu \mathrm{g} / \mathrm{l}$ \\
\hline
\end{tabular}


Table 3. Mean daily discharge calculated for 5 gaging sites in proximity to the MNRR reach for the period August 17 through September 26, 2001. (Note: The calculated mean daily discharges are based on provisional discharge measurements.)

\begin{tabular}{|c|c|c|c|c|c|}
\hline \multirow[b]{2}{*}{ Date } & \multicolumn{5}{|c|}{ Mean Daily Discharge (cfs) } \\
\hline & $\begin{array}{c}\text { Gavins Point } \\
\text { Dam }\end{array}$ & $\begin{array}{l}\text { Scotland } \\
\text { Gage }\end{array}$ & $\begin{array}{c}\text { Vermillion } \\
\text { Gage }\end{array}$ & $\begin{array}{l}\text { Akron } \\
\text { Gage }\end{array}$ & $\begin{array}{l}\text { Sioux City } \\
\text { Gage }\end{array}$ \\
\hline 17-Aug-2001 & 25,003 & 1,259 & 137 & 1,603 & 29,239 \\
\hline 18-Aug2001 & 25,478 & 1,272 & 137 & 1,539 & 28,012 \\
\hline 19-Aug2001 & 25,499 & 1,276 & 133 & 1,502 & 28,246 \\
\hline 20-Aug2001 & 25,494 & 1,263 & 127 & 1,466 & 28,296 \\
\hline 21-Aug2001 & 25,970 & 1,239 & 128 & 1,397 & 28,413 \\
\hline 22-Aug2001 & 25,993 & 1,229 & 120 & 1,364 & 28,919 \\
\hline 23-Aug2001 & 26,208 & 1,227 & 141 & 1,281 & 28,838 \\
\hline 24-Aug2001 & 25,997 & 1,235 & 143 & 1,270 & 28,832 \\
\hline 25-Aug2001 & 26,005 & 1,219 & 147 & 1,250 & 28,820 \\
\hline 26-Aug2001 & 26,003 & 1,220 & 145 & 1,213 & 28,669 \\
\hline 27-Aug2001 & 25,997 & 1,208 & 142 & 1,189 & 28,585 \\
\hline 28-Aug2001 & 26,000 & 1,196 & 138 & 1,148 & 28,578 \\
\hline 29-Aug2001 & 26,000 & 1,181 & 133 & 1,123 & 28,655 \\
\hline 30-Aug2001 & 26,000 & 1,172 & 133 & 1,070 & 28,917 \\
\hline 31-Aug2001 & 26,000 & 1,156 & 132 & 1,040 & 28,418 \\
\hline 1-Sep2001 & 25,996 & 1,131 & 132 & 1,255 & 28,122 \\
\hline 2-Sep2001 & 25,998 & 1,110 & 140 & 1,111 & 28,551 \\
\hline 3-Sep2001 & 25,999 & 1,103 & 134 & 978 & 28,441 \\
\hline 4-Sep2001 & 26,796 & 1,091 & 123 & 918 & 28,148 \\
\hline 5-Sep2001 & 27,504 & 1,066 & 120 & 894 & 29,012 \\
\hline 6-Sep2001 & 27,957 & 1,054 & 121 & 608 & 29,660 \\
\hline 7-Sep2001 & 27,994 & 1,092 & 121 & 592 & 30,171 \\
\hline 8-Sep2001 & 28,005 & 1,119 & 119 & 566 & 30,760 \\
\hline 9-Sep2001 & 27,998 & 1,124 & 118 & 566 & 30,663 \\
\hline 10-Sep2001 & 28,002 & 1,144 & 123 & 583 & 30,318 \\
\hline 11-Sep2001 & 27,998 & 1,125 & 130 & 576 & 30,190 \\
\hline 12-Sep2001 & 27,753 & 1,110 & 126 & 554 & 30,303 \\
\hline 13-Sep2001 & 27,501 & 1,032 & 122 & 529 & 30,371 \\
\hline 14-Sep2001 & 27,504 & 1,088 & 129 & 549 & 31,169 \\
\hline 15-Sep2001 & 27,991 & 1,110 & 139 & 571 & 31,668 \\
\hline 16-Sep2001 & 27,081 & 1,135 & 144 & 641 & 31,049 \\
\hline 17-Sep2001 & 25,480 & 1,157 & 148 & 796 & 30,532 \\
\hline 18-Sep2001 & 25,005 & 1,171 & 153 & 845 & 28,352 \\
\hline 19-Sep2001 & 24,999 & 1,161 & 158 & 819 & 27,627 \\
\hline 20-Sep2001 & 25,001 & 1,144 & 155 & 717 & 27,503 \\
\hline 21-Sep2001 & 25,010 & 1,119 & 151 & 665 & 27,400 \\
\hline 22-Sep2001 & 25,002 & 1,087 & 146 & 649 & 27,457 \\
\hline 23-Sep2001 & 25,007 & 1,061 & 141 & 669 & 27,365 \\
\hline 24-Sep2001 & 25,004 & 1,029 & 136 & 621 & 27,158 \\
\hline 25-Sep2001 & 25,499 & 997 & 133 & 579 & 26,731 \\
\hline 26-Sep2001 & 25,998 & 974 & 132 & 558 & 27,067 \\
\hline Mean & 26,286 & 1,144 & 135 & 924 & 28,908 \\
\hline
\end{tabular}


Table 4. Water balance based on the mean daily discharges calculated the 5 gage sites for the period August 17 through September 26, 2001.

\begin{tabular}{|c|c|c|c|c|}
\hline Date & $\begin{array}{c}\mathrm{GPT}+\underset{\text { (cfs) }}{\mathrm{SCT}}+\mathrm{VER}^{*} \\
\text { (c) }\end{array}$ & $\begin{array}{l}\mathrm{SC} ! \mathrm{AKR}^{*} \\
\text { (cfs) }\end{array}$ & $\begin{array}{c}\text { RPD }^{* *} \\
\text { (Same Day) }\end{array}$ & $\begin{array}{c}\text { RPD }^{* *} \\
\text { (1-Day Delay) }\end{array}$ \\
\hline 17-Aug-2001 & 26,399 & 27,636 & 4.58 & \\
\hline 18-Aug-2001 & 26,887 & 26,473 & 1.55 & 0.28 \\
\hline 19-Aug-2001 & 26,908 & 26,744 & 0.61 & 0.53 \\
\hline 20-Aug-2001 & 26,884 & 26,830 & 0.20 & 0.29 \\
\hline 21-Aug-2001 & 27,337 & 27,016 & 1.18 & 0.49 \\
\hline 22-Aug-2001 & 27,342 & 27,555 & 0.78 & 0.79 \\
\hline 23-Aug-2001 & 27,576 & 27,557 & 0.07 & 0.78 \\
\hline 24-Aug-2001 & 27,375 & 27,562 & 0.68 & 0.05 \\
\hline 25-Aug-2001 & 27,371 & 27,570 & 0.72 & 0.71 \\
\hline 26-Aug-2001 & 27,368 & 27,456 & 0.32 & 0.31 \\
\hline 27-Aug-2001 & 27,347 & 27,396 & 0.18 & 0.10 \\
\hline 28-Aug-2001 & 27,334 & 27,430 & 0.35 & 0.30 \\
\hline 29-Aug-2001 & 27,314 & 27,532 & 0.79 & 0.72 \\
\hline 30-Aug-2001 & 27,305 & 27,847 & 1.97 & 1.93 \\
\hline 31-Aug-2001 & 27,288 & 27,378 & 0.33 & 0.27 \\
\hline 1-Sep-2001 & 27,259 & 26,867 & 1.45 & 1.55 \\
\hline 2-Sep-2001 & 27,248 & 27,440 & 0.70 & 0.66 \\
\hline 3-Sep-2001 & 27,236 & 27,463 & 0.83 & 0.79 \\
\hline 4-Sep-2001 & 28,010 & 27,230 & 2.82 & 0.02 \\
\hline 5-Sep-2001 & 28,690 & 28,118 & 2.01 & 0.38 \\
\hline 6-Sep-2001 & 29,132 & 29,052 & 0.27 & 1.25 \\
\hline 7-Sep-2001 & 29,207 & 29,579 & 1.27 & 1.52 \\
\hline 8-Sep-2001 & 29,243 & 30,194 & 3.20 & 3.32 \\
\hline 9-Sep-2001 & 29,240 & 30,097 & 2.89 & 2.88 \\
\hline 10-Sep-2001 & 29,269 & 29,735 & 1.58 & 1.68 \\
\hline 11-Sep-2001 & 29,253 & 29,614 & 1.23 & 1.17 \\
\hline 12-Sep-2001 & 28,989 & 29,749 & 2.59 & 1.68 \\
\hline 13-Sep-2001 & 28,655 & 29,842 & 4.06 & 2.90 \\
\hline 14-Sep-2001 & 28,721 & 30,620 & 6.40 & 6.63 \\
\hline 15-Sep-2001 & 29,240 & 31,097 & 6.16 & 7.94 \\
\hline 16-Sep-2001 & 28,360 & 30,408 & 6.97 & 3.92 \\
\hline 17-Sep-2001 & 26,785 & 29,736 & 10.44 & 4.74 \\
\hline 18-Sep-2001 & 26,329 & 27,507 & 4.38 & 2.66 \\
\hline 19-Sep-2001 & 26,318 & 26,808 & 1.84 & 1.80 \\
\hline 20-Sep-2001 & 26,300 & 26,786 & 1.83 & 1.76 \\
\hline 21-Sep-2001 & 26,280 & 26,735 & 1.72 & 1.64 \\
\hline 22-Sep-2001 & 26,235 & 26,808 & 2.16 & 1.99 \\
\hline 23-Sep-2001 & 26,209 & 26,696 & 1.84 & 1.74 \\
\hline 24-Sep-2001 & 26,169 & 26,537 & 1.40 & 1.24 \\
\hline 25-Sep-2001 & 26,629 & 26,152 & 1.81 & 0.06 \\
\hline 26-Sep-2001 & 27,104 & 26,509 & 2.22 & 0.45 \\
\hline \multirow[t]{6}{*}{ Mean } & 27,565 & 27,985 & 2.16 & 1.60 \\
\hline & & Minimum & 0.07 & 0.02 \\
\hline & & $25^{\text {th }}$ Percentile & 0.72 & 0.43 \\
\hline & & Median & 1.58 & 1.21 \\
\hline & & $75^{\text {th }}$ Percentile & 2.59 & 1.84 \\
\hline & & Maximum & 10.44 & 7.94 \\
\hline
\end{tabular}

* GPT = Gavins Point Dam Discharge, SCT = Scotland gage discharge, VER = Vermillion gage discharge, $\mathrm{SC}=$ Sioux City gage discharge, and AKR = Akron gage discharge .

${ }^{* *} \mathrm{RPD}=\left[\left|\mathrm{X}_{1} ! \mathrm{X}_{2}\right| /\left(\left(\mathrm{X}_{1}+\mathrm{X}_{2}\right) / 2\right)\right] \times 100 \%$; where $\mathrm{X}_{1}=(\mathrm{GPT}+\mathrm{SCT}+\mathrm{VER})$, and $\mathrm{X}_{2}=(\mathrm{SC} ! \mathrm{AKR})$. 
Table 5. Summary statistics of water quality conditions monitored at the near-surface thalweg and tributary sites during the scoping study.

\begin{tabular}{|c|c|c|c|c|c|c|c|c|c|c|c|c|c|c|c|c|c|c|c|c|}
\hline \multirow[b]{2}{*}{ Parameter } & \multicolumn{5}{|c|}{ Site 1Ts } & \multicolumn{5}{|c|}{ Site 2Ts } & \multicolumn{5}{|c|}{ Site 3} & \multicolumn{5}{|c|}{ Site 4Ts } \\
\hline & Mean & Med. & Min. & Max. & Obs. & Mean & Med. & Min. & Max. & Obs. & Mean & Med. & Min. & Max. & Obs. & Mean & Med. & Min. & Max. & Obs. \\
\hline Water Temperature $\left({ }^{\circ} \mathrm{C}\right)$ & 21.7 & 22.5 & 18.3 & 24.6 & 6 & 21.5 & 22.3 & 18.0 & 24.5 & 6 & 21.4 & 22.7 & 16.2 & 25.3 & 6 & 21.6 & 22.3 & 17.9 & 24.7 & 6 \\
\hline Dissolved Oxygen $(\mathrm{mg} / \mathrm{l})$ & 7.9 & 7.9 & 7 & 8.8 & 6 & 8.0 & 8.0 & 7.4 & 8.8 & 6 & 7.5 & 7.5 & 6.6 & 8.6 & 6 & 7.9 & 8.0 & 7.4 & 8.6 & 6 \\
\hline pH (S.U.) & --- & 8.3 & 8.3 & 8.4 & 6 & --- & 8.3 & 8.3 & 8.4 & 6 & --- & 8.3 & 8.1 & 8.3 & 6 & --- & 8.3 & 8.3 & 8.3 & 6 \\
\hline Conductivity ( $\mu \mathrm{mhos}$ ) & 832 & 833 & 815 & 848 & 6 & 833 & 835 & 816 & 849 & 6 & 1256 & 1267 & 1180 & 1310 & 6 & 833 & 835 & 817 & 850 & 6 \\
\hline Secchi Depth (Inches) & 25 & 26 & 23 & 28 & 5 & 25 & 24 & 21 & 30 & 6 & 10 & 10 & 10 & 11 & 5 & 25 & 24 & 22 & 28 & 5 \\
\hline Turbidity (NTU) & 12 & 12 & 8 & 17 & 6 & 14 & 14 & 11 & 17 & 6 & 34 & 35 & 19 & 42 & 6 & 13 & 13 & 11 & 17 & 6 \\
\hline Total Suspended Solids (mg/l) & 15 & 13 & 8 & 29 & 6 & 14 & 12 & 6 & 28 & 6 & 55 & 49 & 38 & 100 & 6 & 14 & 12 & 11 & 22 & 6 \\
\hline Total Organic Carbon $(\mathrm{mg} / \mathrm{l})$ & 4.2 & 4.2 & 3.9 & 4.8 & 6 & 4.2 & 4.1 & 3.8 & 4.9 & 6 & 12.5 & 12.5 & 12.0 & 13.0 & 6 & 4.0 & 4.1 & 3.0 & 4.8 & 6 \\
\hline Total Phosphorus (mg/l) & 0.03 & 0.03 & 0.03 & 0.04 & 6 & 0.03 & 0.04 & 0.02 & 0.04 & 6 & 0.47 & 0.48 & 0.38 & 0.53 & 6 & 0.03 & 0.03 & 0.02 & 0.04 & 6 \\
\hline Total Kjeldahl Nitrogen $(\mathrm{mg} / \mathrm{l})$ & 0.3 & 0.1 & $<0.1$ & 0.7 & 6 & 0.3 & 0.1 & 0.1 & 0.6 & 6 & 0.6 & 0.6 & 0.4 & 0.8 & 6 & 0.3 & 0.1 & $<0.1$ & 0.7 & 6 \\
\hline Total Ammonia as $\mathrm{N}(\mathrm{mg} / \mathrm{l})$ & 0.08 & 0.02 & $<0.01$ & 0.24 & 6 & 0.07 & 0.03 & $<0.01$ & 0.22 & 6 & 0.08 & 0.03 & $<0.01$ & 0.25 & 6 & 0.07 & $<0.01$ & $<0.01$ & 0.21 & 6 \\
\hline Nitrate-Nitrite as N (mg/l) & 0.12 & 0.13 & 0.07 & 0.15 & 6 & 0.12 & 0.14 & 0.07 & 0.15 & 6 & 0.06 & $<0.02$ & $<0.02$ & 0.17 & 6 & 0.12 & 0.13 & 0.07 & 0.15 & 6 \\
\hline Chlorophyll a $(\mu \mathrm{g} / \mathrm{l})$ & 13 & 7 & 2 & 48 & 6 & 22 & 9 & 4 & 85 & 6 & 21 & 21 & 11 & 38 & 6 & 10 & 10 & 4 & 16 & 6 \\
\hline Atrazine $(\mu \mathrm{g} / \mathrm{l})$ & 0.06 & 0.06 & $<0.05$ & 0.07 & 3 & 0.06 & $<0.05$ & $<0.05$ & 0.07 & 3 & $<0.05$ & $<0.05$ & $<0.05$ & $<0.05$ & 3 & 0.06 & 0.06 & $<0.05$ & 0.06 & 3 \\
\hline Alachlor $(\mu \mathrm{g} / \mathrm{l})$ & $<0.05$ & $<0.05$ & $<0.05$ & $<0.05$ & 3 & $\mid<0.05$ & $<0.05$ & $<0.05$ & $<0.05$ & 3 & $\mid<0.05$ & $<0.05$ & $<0.05$ & $<0.05$ & 3 & $<0.05$ & $<0.05$ & $<0.05$ & $<0.05$ & 3 \\
\hline \multirow[t]{2}{*}{ Metholachlor $(\mu \mathrm{g} / \mathrm{l})$} & $<0.05$ & $<0.05$ & $<0.05$ & $<0.05$ & 3 & $\mid<0.05$ & $<0.05$ & $<0.05$ & $<0.05$ & 3 & $<0.05$ & $<0.05$ & $<0.05$ & $<0.05$ & 3 & $\mid<0.05$ & $<0.05$ & $<0.05$ & $<0.05$ & 3 \\
\hline & \multicolumn{5}{|c|}{ Site 5Ts } & \multicolumn{5}{|c|}{ Site 6} & \multicolumn{5}{|c|}{ Site 7Ts } & \multicolumn{5}{|c|}{ Site 8Ts } \\
\hline Parameter & Mean & Med. & Min. & Max. & Obs. & Mean & Med. & Min. & Max. & Obs. & Mean & Med. & Min. & Max. & Obs. & Mean & Med. & Min. & Max. & Obs. \\
\hline Water Temperature $\left({ }^{\circ} \mathrm{C}\right)$ & 21.7 & 22.6 & 17.0 & 24.5 & 6 & 20.3 & 21.4 & 14.0 & 24.3 & 6 & 21.2 & 21.8 & 17.0 & 24.2 & 5 & 22.2 & 23.5 & 17.4 & 25.0 & 6 \\
\hline Dissolved Oxygen $(\mathrm{mg} / \mathrm{l})$ & 8.5 & 8.5 & 7.9 & 9.2 & 6 & 8.7 & 8.7 & 7.9 & 9.3 & 5 & 8.7 & 8.7 & 8.3 & 9.1 & 4 & 9.0 & 9.1 & 8.7 & 9.4 & 5 \\
\hline $\mathrm{pH}$ (S.U.) & --- & 8.3 & 8.3 & 8.4 & 6 & --- & 8.2 & 8.0 & 8.3 & 6 & --- & 8.4 & 8.3 & 8.4 & 5 & --- & 8.4 & 8.3 & 8.4 & 6 \\
\hline Conductivity ( $\mu \mathrm{mhos}$ ) & 853 & 853 & 836 & 865 & 6 & 1385 & 1385 & 1361 & 1408 & 6 & 864 & 869 & 847 & 874 & 5 & 851 & 854 & 834 & 865 & 6 \\
\hline Secchi Depth (Inches) & 20 & 21 & 19 & 21 & 5 & 12 & 12 & 11 & 14 & 5 & 19 & 18 & 18 & 20 & 5 & 19 & 19 & 18 & 20 & 5 \\
\hline Turbidity (NTU) & 18 & 18 & 16 & 22 & 6 & 30 & 27 & 25 & 37 & 6 & 21 & 22 & 18 & 23 & 6 & 22 & 21 & 19 & 29 & 6 \\
\hline Total Suspended Solids (mg/l) & 29 & 24 & 21 & 54 & 6 & 41 & 39 & 30 & 62 & 6 & 37 & 31 & 25 & 70 & 6 & 40 & 33 & 30 & 80 & 6 \\
\hline Total Organic Carbon $(\mathrm{mg} / \mathrm{l})$ & 4.8 & 4.4 & 4.1 & 6.4 & 6 & 11.2 & 11.0 & 11.0 & 12.0 & 6 & 4.8 & 4.8 & 4.5 & 5.5 & 6 & 4.4 & 4.4 & 4.1 & 5.2 & 6 \\
\hline Total Phosphorus (mg/l) & 0.06 & 0.06 & 0.05 & 0.07 & 6 & 0.21 & 0.21 & 0.18 & 0.26 & 6 & 0.08 & 0.08 & 0.06 & 0.09 & 6 & 0.07 & 0.08 & 0.06 & 0.08 & 6 \\
\hline Total Kjeldahl Nitrogen $(\mathrm{mg} / \mathrm{l})$ & 0.2 & $<0.1$ & $<0.1$ & 0.6 & 6 & 0.5 & 0.6 & 0.1 & 0.9 & 6 & 0.3 & 0.1 & $<0.1$ & 0.7 & 6 & 0.3 & 0.1 & $<0.1$ & 0.6 & 6 \\
\hline Total Ammonia as $\mathrm{N}(\mathrm{mg} / \mathrm{l})$ & 0.06 & 0.01 & $<0.01$ & 0.19 & 6 & 0.07 & 0.03 & $<0.01$ & 0.21 & 6 & 0.06 & $<0.01$ & $<0.01$ & 0.20 & 6 & 0.06 & 0.02 & $<0.01$ & 0.19 & 6 \\
\hline Nitrate-Nitrite as N (mg/l) & 0.13 & 0.14 & 0.08 & 0.17 & 6 & 0.05 & $<0.02$ & $<0.02$ & 0.13 & 6 & 0.12 & 0.14 & 0.05 & 0.16 & 6 & 0.09 & 0.10 & $<0.02$ & 0.17 & 6 \\
\hline Chlorophyll a $(\mu \mathrm{g} / \mathrm{l})$ & 19 & 9 & $<1$ & 79 & 6 & 24 & 27 & 100 & 35 & 6 & 12 & 14 & 2 & 22 & 6 & 10 & 10 & 2 & 19 & 6 \\
\hline Atrazine $(\mu \mathrm{g} / \mathrm{l})$ & 0.06 & $<0.05$ & $<0.05$ & 0.09 & 3 & 0.21 & 0.27 & 0.07 & 0.28 & 3 & 0.07 & 0.07 & $<0.05$ & 0.08 & 3 & $<0.05$ & $<0.05$ & $<0.05$ & 0.06 & 3 \\
\hline Alachlor $(\mu \mathrm{g} / \mathrm{l})$ & $<0.05$ & $<0.05$ & $<0.05$ & $<0.05$ & 3 & $<0.05$ & $<0.05$ & $<0.05$ & $<0.05$ & 3 & $<0.05$ & $<0.05$ & $<0.05$ & $<0.05$ & 3 & $<0.05$ & $<0.05$ & $<0.05$ & $<0.05$ & 3 \\
\hline Metholachlor $(\mu \mathrm{g} / \mathrm{l})$ & $<0.05$ & $<0.05$ & $<0.05$ & $<0.05$ & 3 & $<0.05$ & $<0.05$ & $<0.05$ & $<0.05$ & 3 & $<0.05$ & $<0.05$ & $<0.05$ & $<0.05$ & 3 & $<<0.05$ & $<0.05$ & $<0.05$ & $<0.05$ & 3 \\
\hline
\end{tabular}

Mean $=$ Mean value of observations. (Values below detection limit were set at the detection limit when calculating mean values.)

Med. $=$ Median value of observations.

Min. = Minimum value of observations.

Max. = Maximum value of observations

Obs. $=$ Number of observations on which the mean, median, minimum, and maximum are based 
Table 6. Mean turbidity, Secchi depth, and conductivity values determined from data collected at Sites 2Ts, 3, 3T1, 3T2, 3T3, 3T4, 4B, 5Ts, 6, 7Ts, and 8Ts during the scoping study.

\begin{tabular}{|c|c|c|c|}
\hline \hline Site & $\begin{array}{c}\text { Turbidity } \\
\text { (NTU) }\end{array}$ & $\begin{array}{c}\text { Secchi Depth } \\
\text { (inches) }\end{array}$ & $\begin{array}{c}\text { Conductivity } \\
\text { ( } \mu \text { mhos) }\end{array}$ \\
\hline 2Ts & 14 & 25 & 833 \\
\hline 3 & 34 & 10 & 1,256 \\
\hline $3 T 1$ & 47 & 10 & 1,290 \\
\hline $3 T 2$ & 42 & 10 & 1,243 \\
\hline $3 T 3$ & 36 & 11 & 1,248 \\
\hline $3 T 4$ & 34 & 12 & 1,151 \\
\hline $4 \mathrm{~B}(1)^{*}$ & 32 & 13 & 1,050 \\
\hline 4B(2) & 19 & 19 & 859 \\
\hline 5Ts & 18 & 20 & 853 \\
\hline 6 & 30 & 12 & 1,385 \\
\hline 7Ts & 21 & 19 & 864 \\
\hline 8Ts & 22 & 19 & 851 \\
\hline
\end{tabular}

4B(1) was located in a backwater area near the north bank of the Missouri River and was in a noticeable plume formed by the James River inflow. 4B(2) was in a backwater area away from the north bank and just on the edge of the James River plume. See Plate 5.

Table 7. Total suspended solids loading estimates for the James and Vermillion Rivers for selected days during the scoping study.

\section{James River:}

\begin{tabular}{|c|r|r|r|r|}
\hline Date & \multicolumn{1}{|c|}{$\begin{array}{c}\text { Mean Daily } \\
\text { Discharge } \\
\text { (cfs) }\end{array}$} & \multicolumn{2}{c|}{$\begin{array}{c}\text { TSS } \\
\text { Concentration } \\
\text { (mg/l) }\end{array}$} & \multicolumn{2}{c|}{$\begin{array}{c}\text { TSS } \\
\text { Flux Rate } \\
\text { (Ibs/sec) }\end{array}$} & $\begin{array}{c}\text { Estimated TSS } \\
\text { Load } \\
\text { (tons/day) }\end{array}$ \\
\hline 22-Aug-2001 & 1,229 & 100 & 7.67 & 331.4 \\
\hline 29-Aug-2001 & 1,181 & 38 & 2.80 & 121.0 \\
\hline 5-Sep-2001 & 1,066 & 44 & 2.93 & 126.5 \\
\hline 12-Sep-2001 & 1,110 & 52 & 3.60 & 155.7 \\
\hline 19-Sep-2001 & 1,161 & 53 & 3.84 & 165.9 \\
\hline 26-Sep-2001 & 974 & 45 & 2.74 & 118.2 \\
\hline & & & & \\
\hline Average & 1,120 & 55 & 3.93 & 169.8 \\
\hline
\end{tabular}

\section{Vermillion River:}

\begin{tabular}{|c|c|c|c|c|}
\hline Date & $\begin{array}{l}\text { Mean Daily } \\
\text { Discharge } \\
\text { (cfs) }\end{array}$ & $\begin{array}{c}\text { TSS } \\
\begin{array}{c}\text { Concentration } \\
\text { (mg/l) }\end{array} \\
\end{array}$ & $\begin{array}{l}\text { TSS } \\
\text { Flux Rate } \\
\text { (Ibs/sec) }\end{array}$ & $\begin{array}{c}\text { Estimated TSS } \\
\text { Load } \\
\text { (tons/day) }\end{array}$ \\
\hline 22-Aug-2001 & 120 & 62 & 0.46 & 20.1 \\
\hline 29-Aug-2001 & 133 & 32 & 0.27 & 11.5 \\
\hline 5-Sep-2001 & 120 & 30 & 0.22 & 9.7 \\
\hline 12-Sep-2001 & 126 & 45 & 0.35 & 15.3 \\
\hline 19-Sep-2001 & 158 & 33 & 0.33 & 14.1 \\
\hline 26-Sep-2001 & 132 & 46 & 0.38 & 16.4 \\
\hline Averaqe & 132 & 41 & 0.34 & 14.5 \\
\hline
\end{tabular}


Table 8. Analysis results and percent relative difference (RPD) of collocated samples collected during the scoping study. RPD values calculated only if analysis results were above the reporting limit for that parameter.

\begin{tabular}{|c|c|c|c|c|c|c|c|c|c|}
\hline & \multicolumn{3}{|c|}{\begin{tabular}{|c|} 
22-Aug-2001 \\
\end{tabular}} & \multicolumn{3}{|c|}{\begin{tabular}{|r|} 
29-Aug-2001 \\
\end{tabular}} & \multicolumn{3}{|c|}{$\begin{array}{r}\text { 5-Sep-2001 } \\
\end{array}$} \\
\hline Parameter & Duplicate & \begin{tabular}{l|l} 
Site 3 & \\
\end{tabular} & \begin{tabular}{l|l} 
RPD $^{*}$ & [ \\
\end{tabular} & Duplicate & Site 5Ts & RPD* & Duplicate & Site 7Ts & RPD $^{*}$ \\
\hline Alachlor $(\mu \mathrm{g} / \mathrm{l})$ & $<0.05$ & $<0.05$ & BRL & & & & $<0.05$ & $<0.05$ & $\mathrm{BRL}$ \\
\hline Atrazine $(\mu \mathrm{g} / \mathrm{l})$ & $<0.05$ & $<0.05$ & $\mathrm{BRL}$ & & & & 0.06 & 0.08 & $\mathrm{BRL}$ \\
\hline Chlorophyll a $(\mu \mathrm{g} / \mathrm{l})$ & 4 & 11 & 93.3 & 9 & 7 & 25.0 & -- & 16 & -- \\
\hline Metolachlor $(\mu \mathrm{g} / \mathrm{l})$ & $<0.05$ & $<0.05$ & BRL & & & & $<0.05$ & $<0.05$ & BRL \\
\hline Nitrate/Nitrite as N (mg/l) & 0.12 & 0.12 & 0.0 & 0.15 & 0.16 & 6.5 & 0.04 & 0.05 & BRL \\
\hline Total Ammonia as $\mathrm{N}(\mathrm{mg} / \mathrm{l})$ & $<0.01$ & $<0.01$ & $\mathrm{BRL}$ & $<0.01$ & $<0.01$ & $\mathrm{BRL}$ & $<0.01$ & $<0.01$ & $\overline{B R L}$ \\
\hline Total Kjedahl Nitrogen (mg/l) & 0.84 & 0.73 & 14.0 & 0.15 & $<0.1$ & $\mathrm{BRL}$ & $<0.1$ & $<0.1$ & $\overline{B R L}$ \\
\hline Total Organic Carbon (mg/l) & 13 & 13 & 0.0 & 4.5 & 4.4 & 2.3 & 4.5 & 4.7 & 4.4 \\
\hline Total Phosphorus (mg/l) & 0.56 & 0.53 & 5.5 & 0.08 & 0.07 & 13.3 & 0.08 & 0.09 & 11.8 \\
\hline Total Suspended Solids (mg/l) & 104 & 100 & 3.9 & 27 & 26 & 3.8 & 32 & 37 & 14.5 \\
\hline Turbidity (NTU) & 39 & 19 & 69.0 & 21 & 22 & 4.7 & 20 & 21 & 4.9 \\
\hline & \multicolumn{3}{|c|}{\begin{tabular}{|l|}
$12-S e p-2001$ \\
\end{tabular}} & \multicolumn{3}{|c|}{\begin{tabular}{|r|}
$19-S e p-2001$ \\
\end{tabular}} & \multicolumn{3}{|c|}{ 26-Sep-2001 } \\
\hline Parameter & Duplicate & Site 1Ts & RPD* & Duplicate & Site 8Ts & RPD* & Duplicate & Site 8Ts & RPD* \\
\hline Alachlor $(\mu \mathrm{g} / \mathrm{l})$ & & & & $<0.05$ & $<0.05$ & $\mathrm{BRL}$ & & & \\
\hline Atrazine $(\mu \mathrm{g} / \mathrm{l})$ & & & & $<0.05$ & $<0.05$ & $\mathrm{BRL}$ & & & \\
\hline Chlorophyll a ( $\mu \mathrm{g} / \mathrm{l})$ & 2 & 6 & BRL & 14 & 12 & 15.4 & 9 & 10 & 10.5 \\
\hline Metolachlor $(\mu \mathrm{g} / \mathrm{l})$ & & & & $<0.05$ & $<0.05$ & $\mathrm{BRL}$ & & & \\
\hline Nitrate/Nitrite as N (mg/l) & 0.07 & 0.07 & BRL & 0.17 & 0.17 & 0.0 & 0.07 & 0.09 & $\mathrm{BRL}$ \\
\hline Total Ammonia as $\mathrm{N}(\mathrm{mg} / \mathrm{l})$ & 0.02 & $<0.01$ & BRL & 0.19 & 0.19 & 0.0 & 0.14 & 0.13 & 7.4 \\
\hline Total Kjedahl Nitrogen (mg/l) & 0.12 & $<0.1$ & BRL & 0.48 & 0.54 & 11.8 & 0.58 & 0.56 & 3.5 \\
\hline Total Organic Carbon (mg/l) & 3.4 & 3.9 & 13.7 & 4.0 & 4.1 & 2.5 & 4.5 & 4.4 & 2.3 \\
\hline Total Phosphorus (mg/l) & 0.04 & 0.03 & 28.6 & 0.07 & 0.08 & 13.3 & 0.07 & 0.06 & 15.4 \\
\hline Total Suspended Solids $(\mathrm{mg} / \mathrm{l})$ & 11 & 13 & 16.7 & 27 & 34 & 23.0 & 27 & 30 & 10.5 \\
\hline Turbidity (NTU) & 14 & 14 & 0.0 & 21 & 19 & 10.0 & 19 & 19 & 0.0 \\
\hline & & & RPD Sur & Immary St & atistics & & & & \\
\hline Parameter & Mean & Minimum & \begin{tabular}{c|}
$25^{\text {th }}$ \\
Percentile
\end{tabular} & Median & $\begin{array}{c}75^{\text {th }} \\
\text { Percentile }\end{array}$ & Maximum & $\begin{array}{l}\text { No. of } \\
\text { Obs. }{ }^{* *}\end{array}$ & & \\
\hline Alachlor $(\mu \mathrm{g} / \mathrm{l})$ & --- & --- & --- & --- & --- & --- & 0 & & \\
\hline Atrazine $(\mu \mathrm{g} / \mathrm{l})$ & \begin{tabular}{l|l}
-- \\
-
\end{tabular} & \begin{tabular}{l|l}
--- & \\
\end{tabular} & \begin{tabular}{l|l}
-- & \\
\end{tabular} & \begin{tabular}{|l|l}
-- \\
\end{tabular} & \begin{tabular}{l|l}
--- & \\
\end{tabular} & \begin{tabular}{|l|l}
-- & \\
\end{tabular} & 0 & & \\
\hline Chlorophyll a ( $\mu \mathrm{g} / \mathrm{l})$ & 36.1 & 10.5 & 14.2 & 20.2 & 42.1 & 93.3 & 4 & & \\
\hline Metolachlor $(\mu \mathrm{g} / \mathrm{l})$ & \begin{tabular}{l|l}
-- \\
\end{tabular} & \begin{tabular}{l|l}
--- & \\
\end{tabular} & \begin{tabular}{l|l}
--- & \\
\end{tabular} & \begin{tabular}{l|l}
-- \\
\end{tabular} & --- & --- & 0 & & \\
\hline Nitrate/Nitrite as N (mg/l) & 2.2 & 0.0 & 0.0 & 0.0 & 3.2 & 6.5 & 3 & & \\
\hline Total Ammonia as N (mg/l) & 3.7 & 0.0 & 1.9 & 3.7 & 5.6 & 7.4 & 2 & & \\
\hline Total Kjedahl Nitrogen (mg/l) & 9.8 & 3.5 & 7.6 & 11.8 & 12.9 & 14.0 & 3 & & \\
\hline Total Organic Carbon (mg/l) & 4.2 & 0.0 & 2.3 & 2.4 & 3.9 & 13.7 & 6 & & \\
\hline Total Phosphorus (mg/l) & 14.7 & 5.5 & 12.2 & 13.3 & 14.9 & 28.6 & 6 & & \\
\hline Total Suspended Solids (mg/l) & 12.1 & 3.8 & 5.6 & 12.5 & 16.1 & 23.0 & 6 & & \\
\hline Turbidity (NTU) & 14.8 & 0.0 & 1.2 & 4.8 & 8.7 & 69.0 & 6 & & \\
\hline
\end{tabular}

* $\mathrm{BRL}=$ Analysis results for one or both of the collocated samples were below the reporting limit for that parameter.

${ }^{* *}$ No. of Obs. $=$ Number of observations on which the RPD summary statistics are based. 


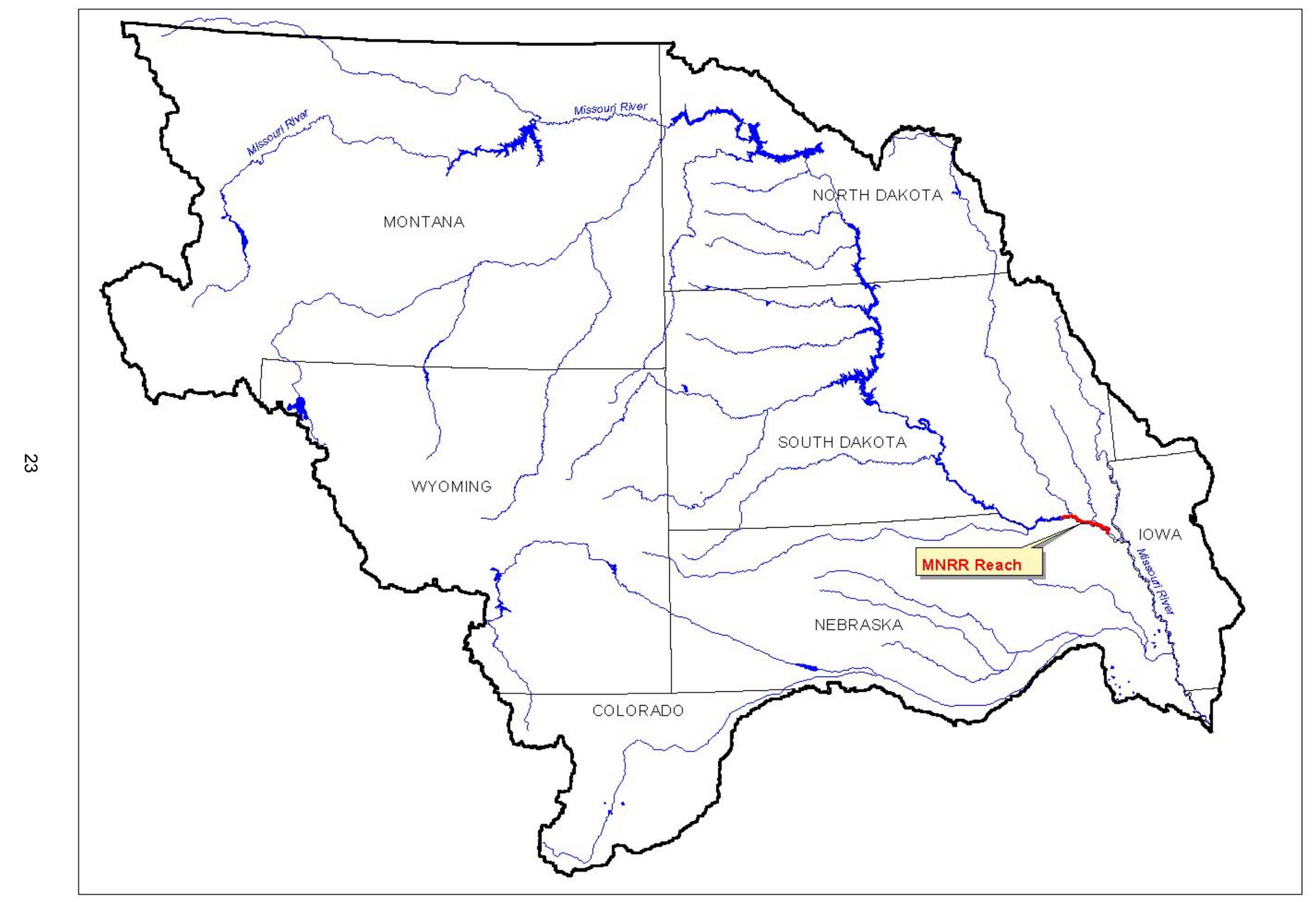

Plate 1. Location of the Missouri National Recreational River (MNRR) reach within the Omaha District. 


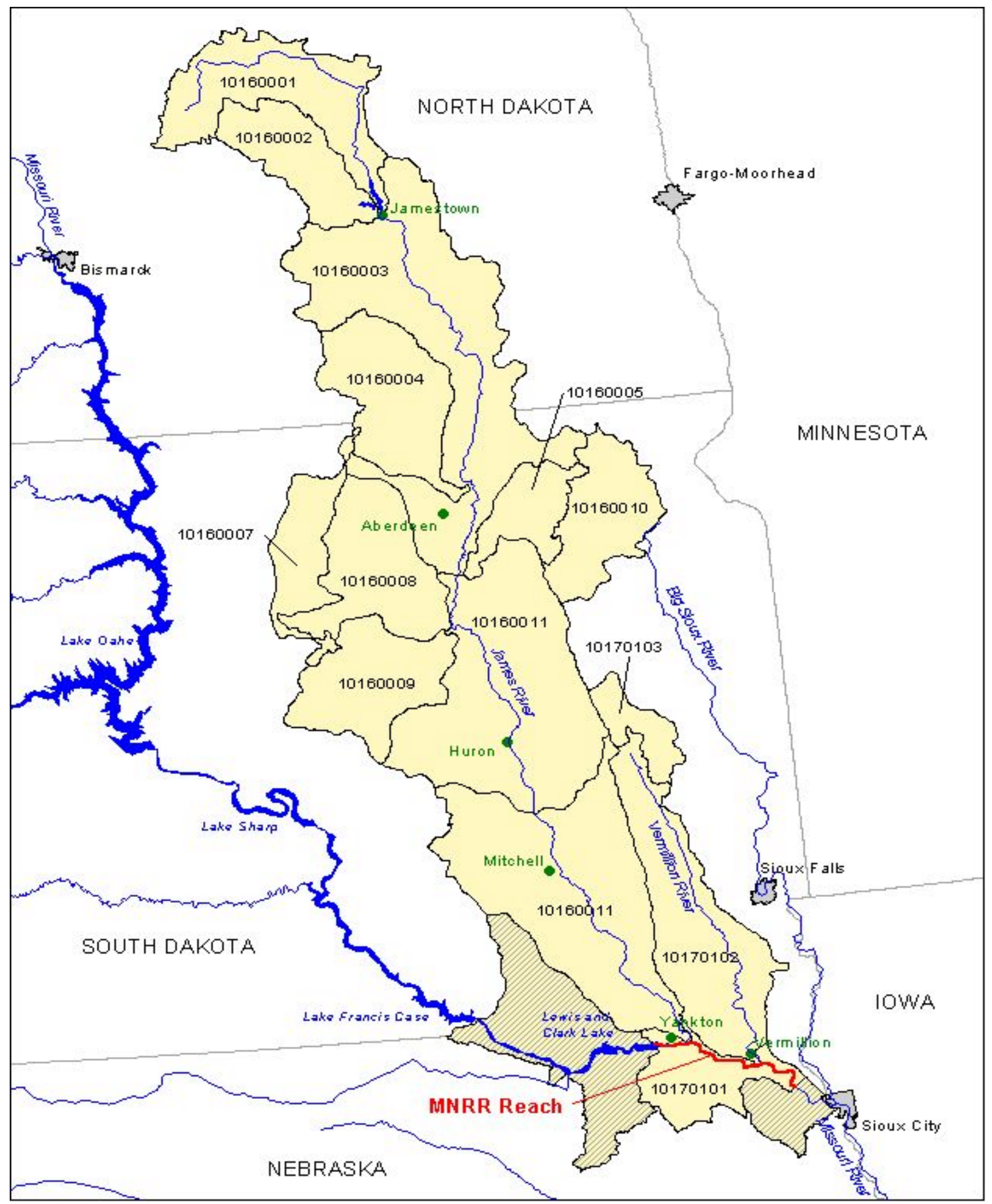

Plate 2. Wiatershed area draining to the MNRR reach below Gavins Point Dam as delineated by 8 -digit $H y d r o l o g i c$ Units (HUCs). Note: The "shaded" area of HUC 10170101 is the are a above Gavins Point Dam and below Ponca, Nebrask a that does not contribute runoff to the MNRR reach. 


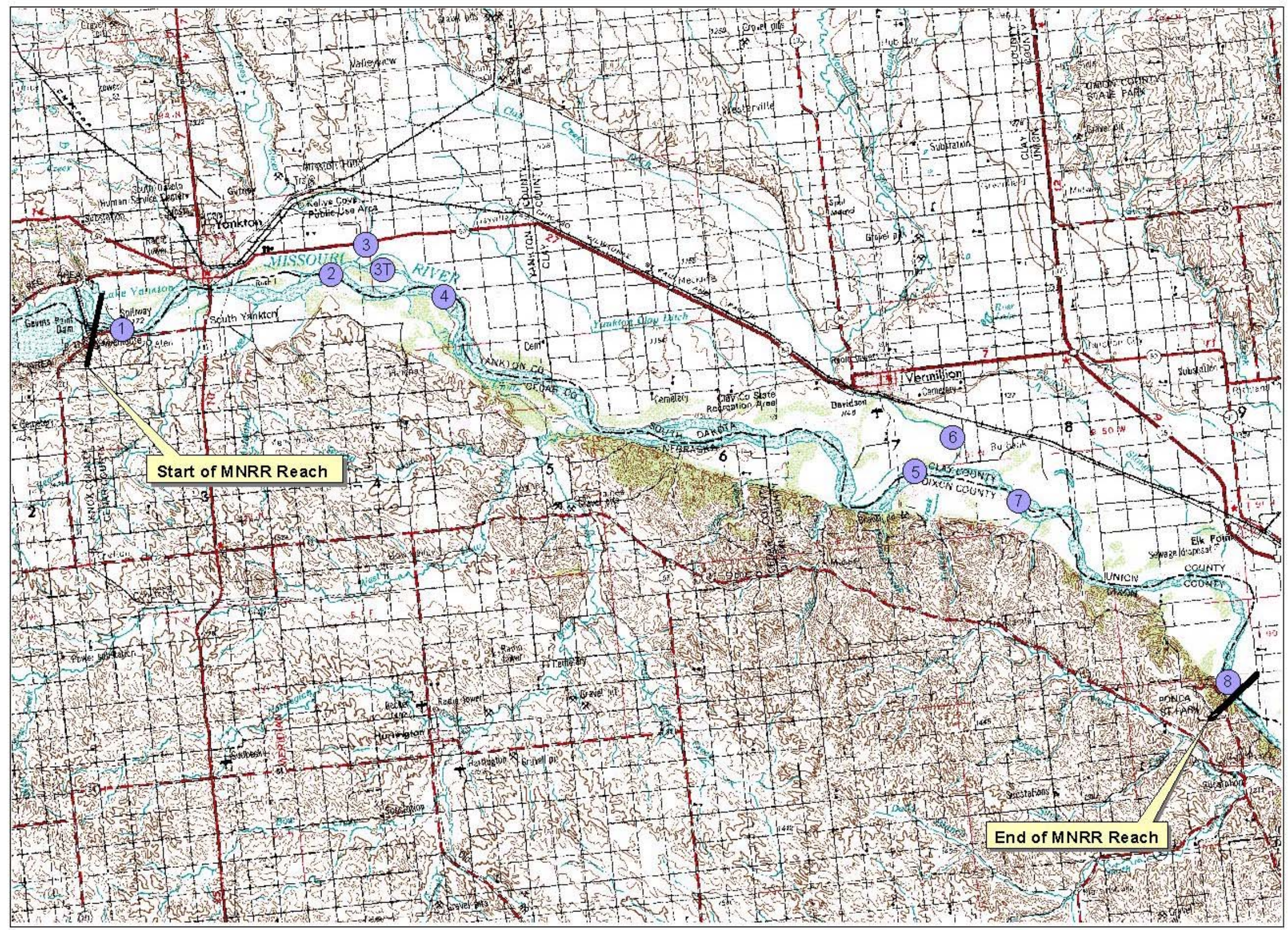

Plate 3. Location of monitoring sites along the MNRR reach where water quality samples were collected as part of the scoping study. 


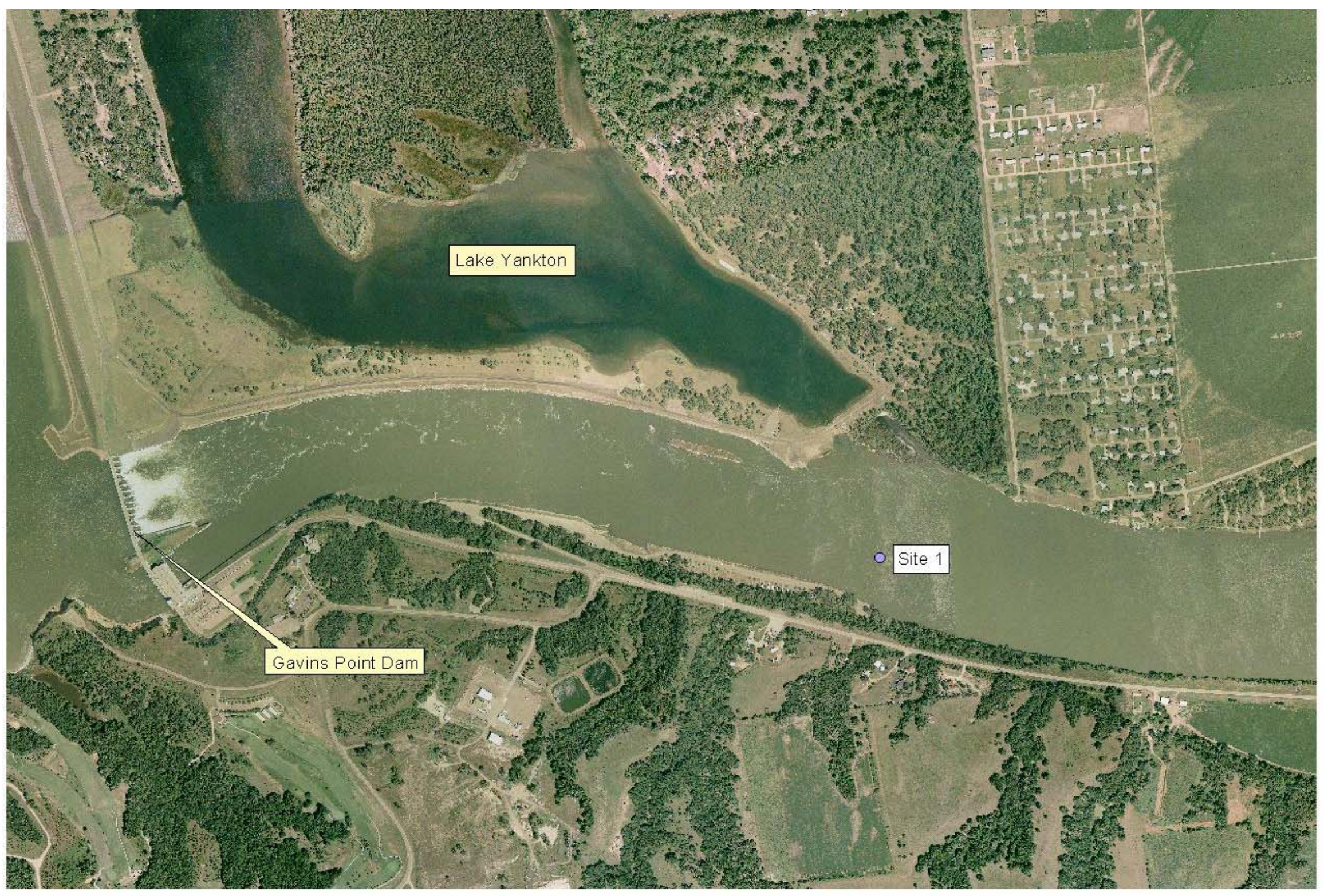

Plate 4. Location of Site 1 based on the average of the obtained GPS coordinates and projected on a 1997 orthophoto of the area. 


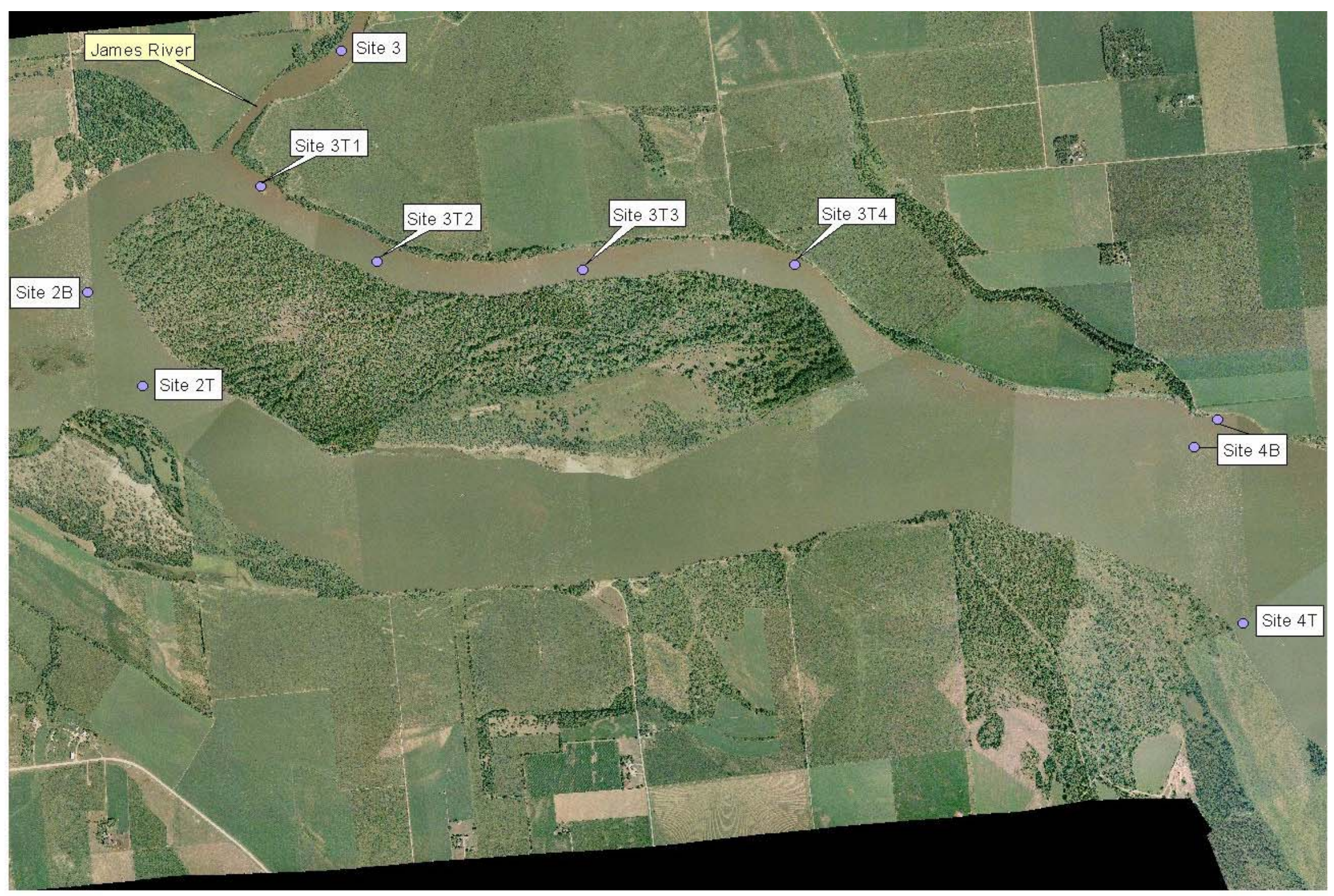

Plate 5. Location of Sites $2 \mathrm{~B}, 2 \mathrm{~T}, 3,3 \mathrm{~T} 1,3 \mathrm{~T} 2,3 \mathrm{~T} 3,3 \mathrm{~T} 4,4 \mathrm{~B}$, and $4 \mathrm{~T}$ based on the average of the obtained GPS coordinates and projected on a 1997 orthophoto of the area 


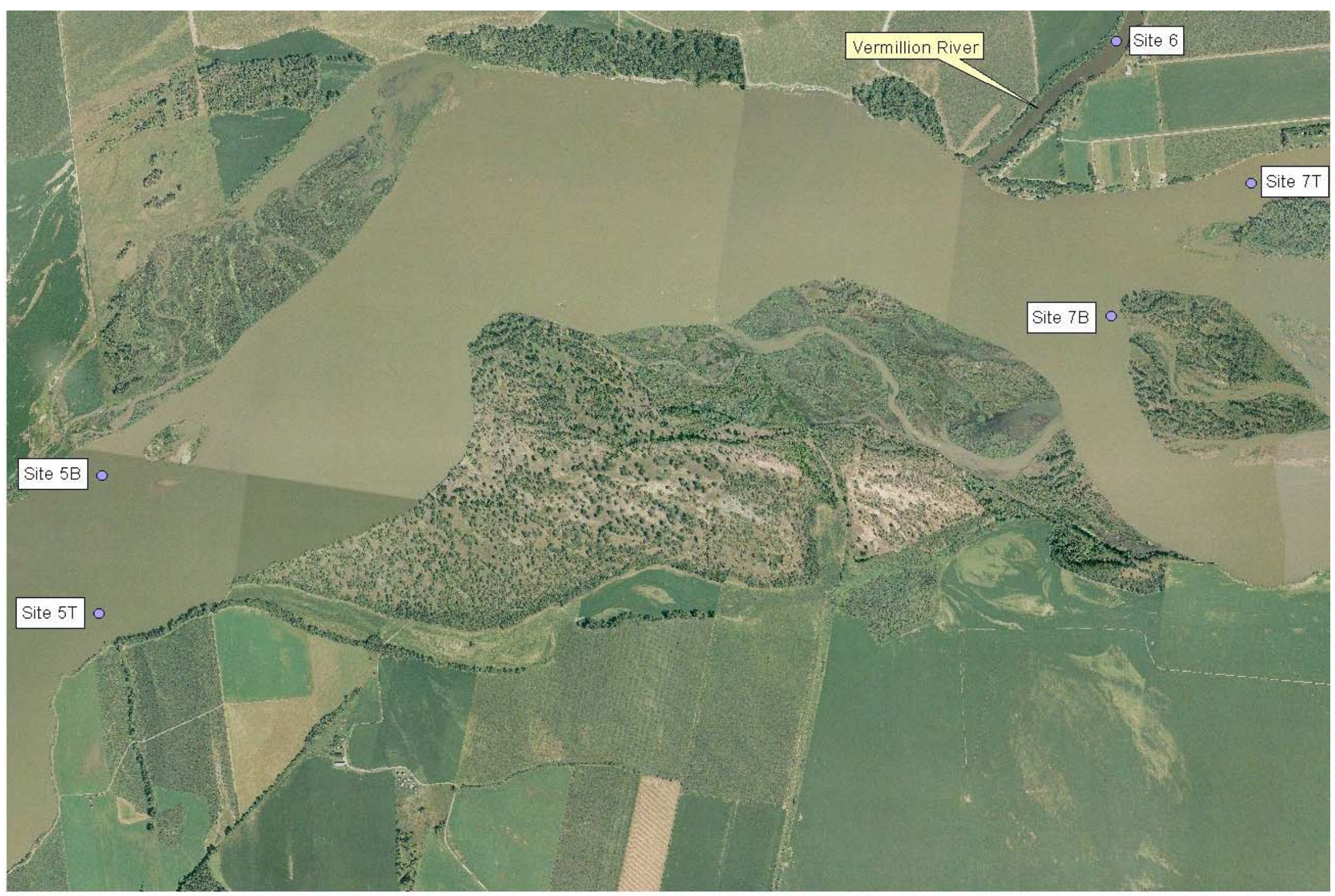

Plate 6. Location of Sites 5B, 5T, 6, 7B, and 7T based on the average of the obtained GPS coordinates and projected on a 1997 orthophoto of the area. 


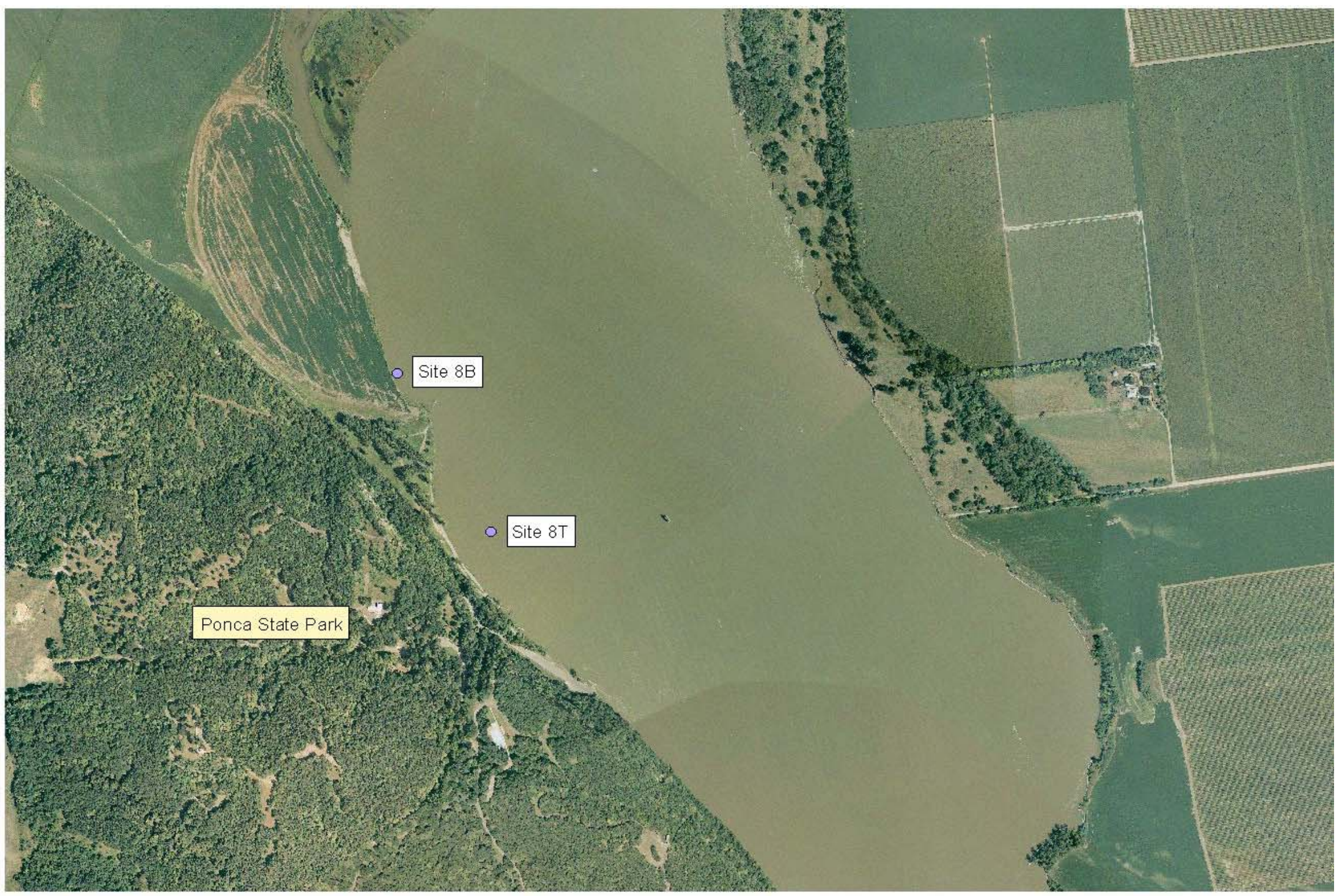

Plate 7. Location of Sites $8 \mathrm{~B}$ and $8 T$ based on the average of the obtained GPS coordinates and projected on a 1997 orthophoto of the area 


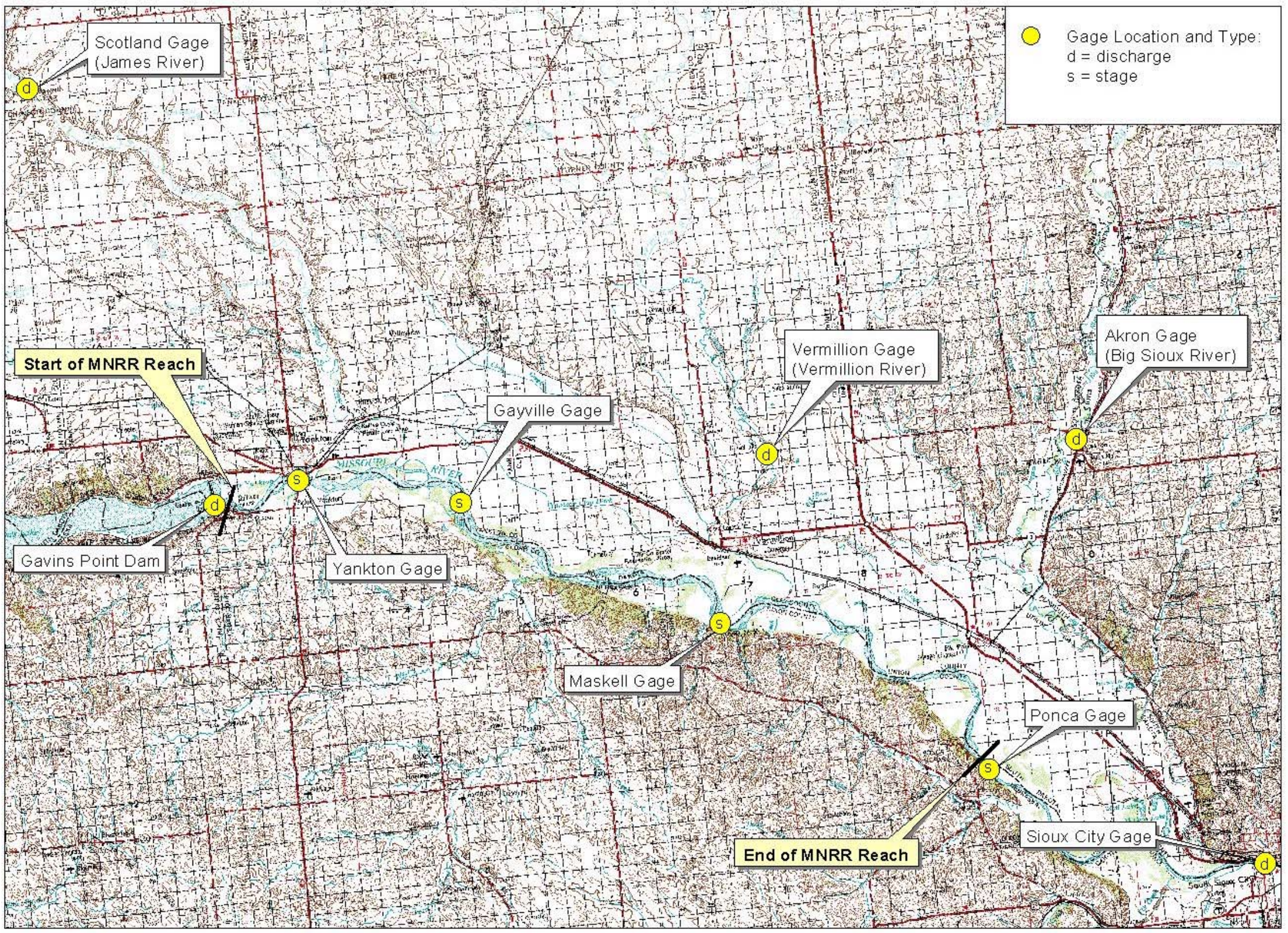

Plate 8. Location of gaging stations along and in proximity to the MNRR reach 

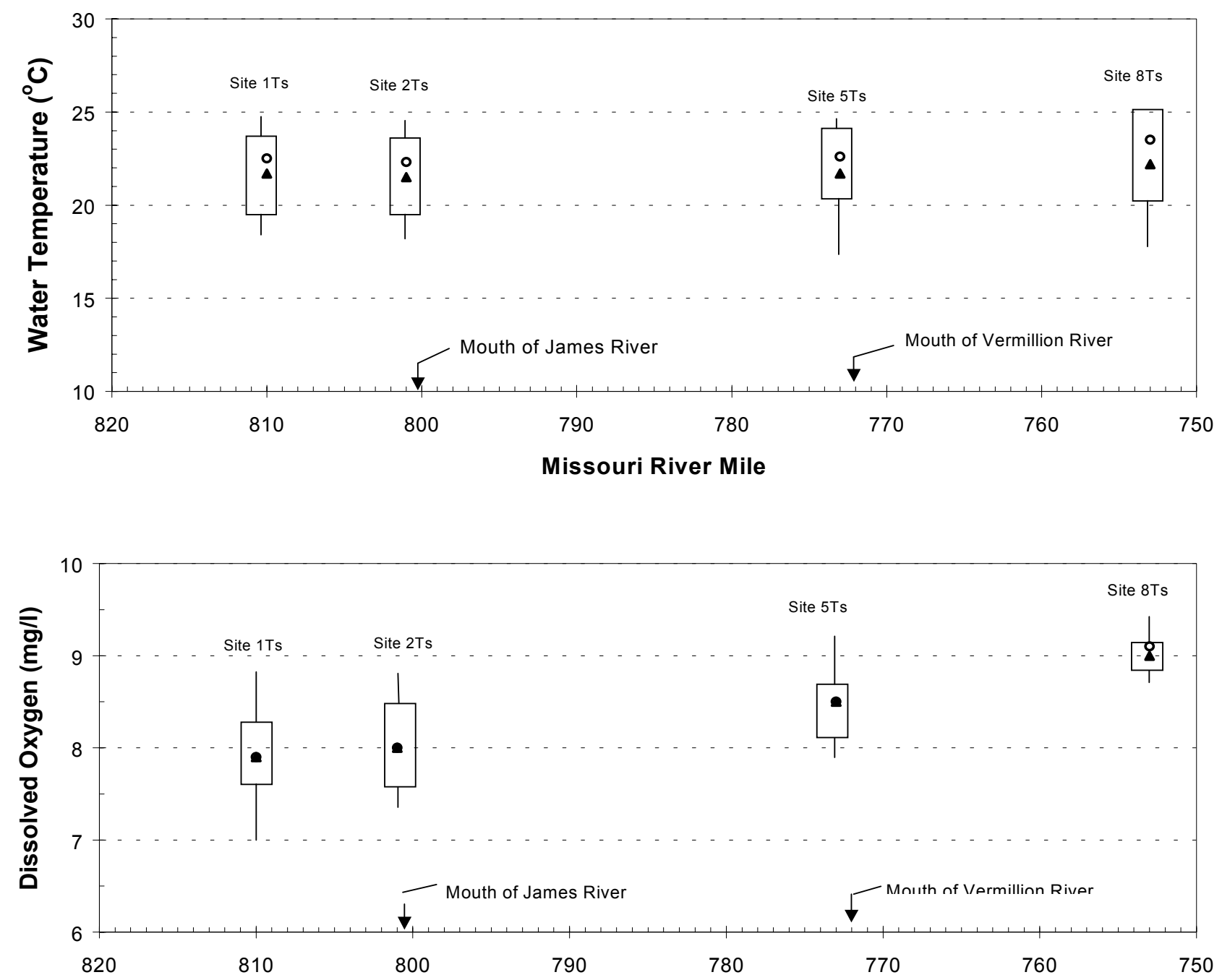

Missouri River Mile

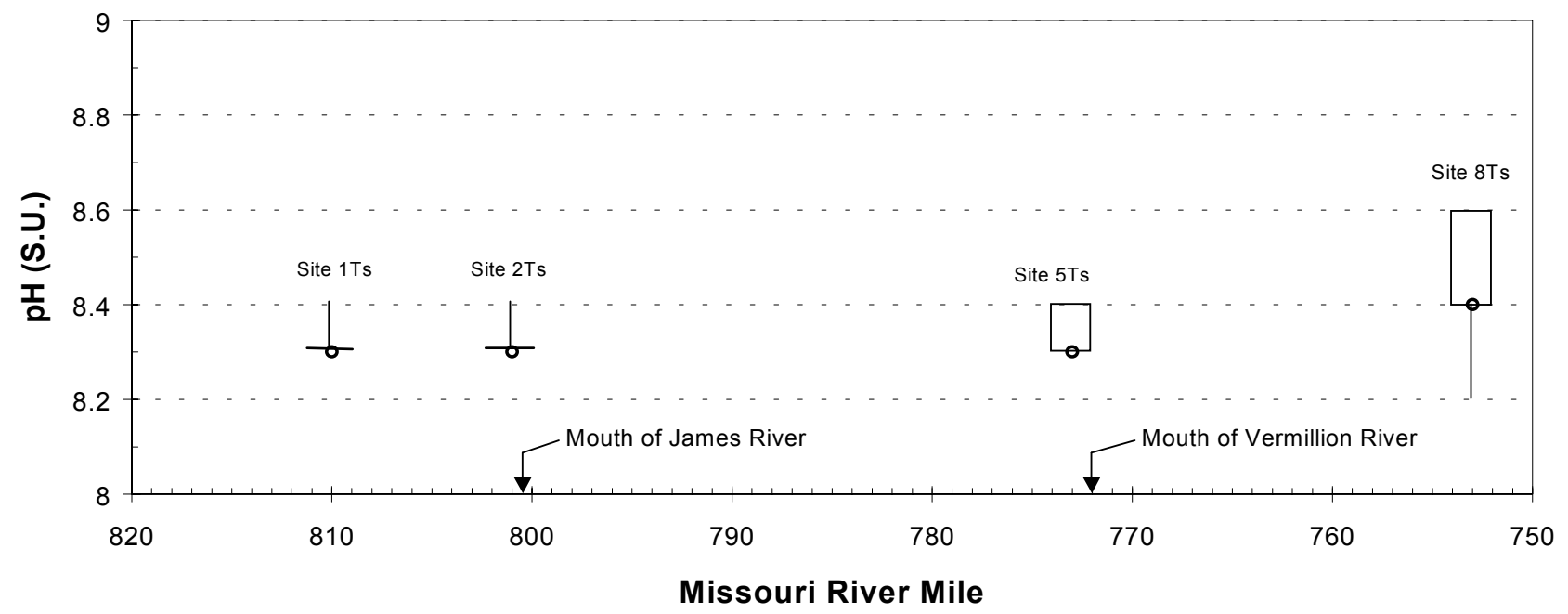

Figure 9. Box plots of water quality parameters monitored at Sites $1 \mathrm{Ts}, 2 \mathrm{Ts}, 5 \mathrm{Ts}$, and 8Ts during the scoping study. 

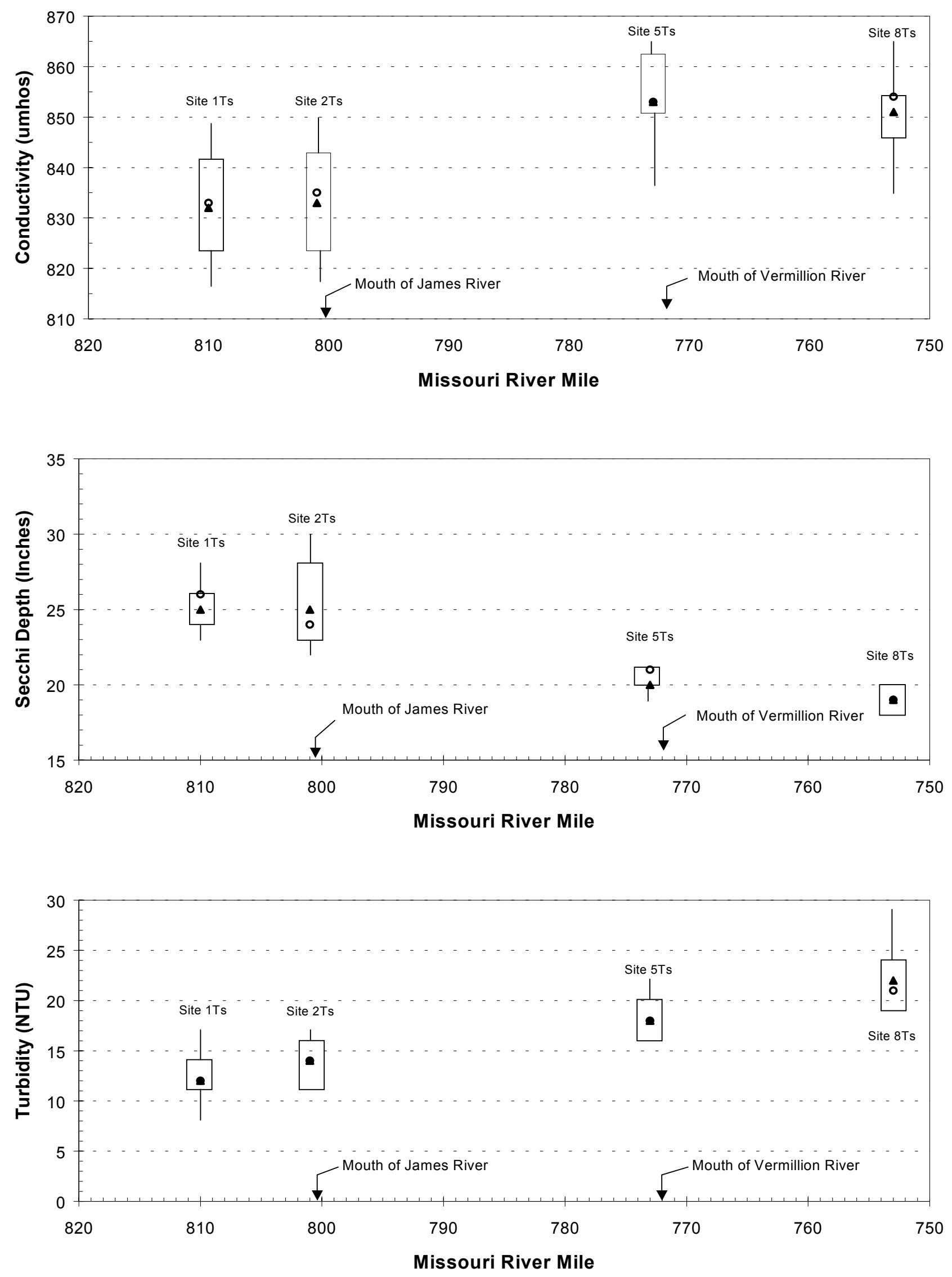

Figure 9. (Continued.) 

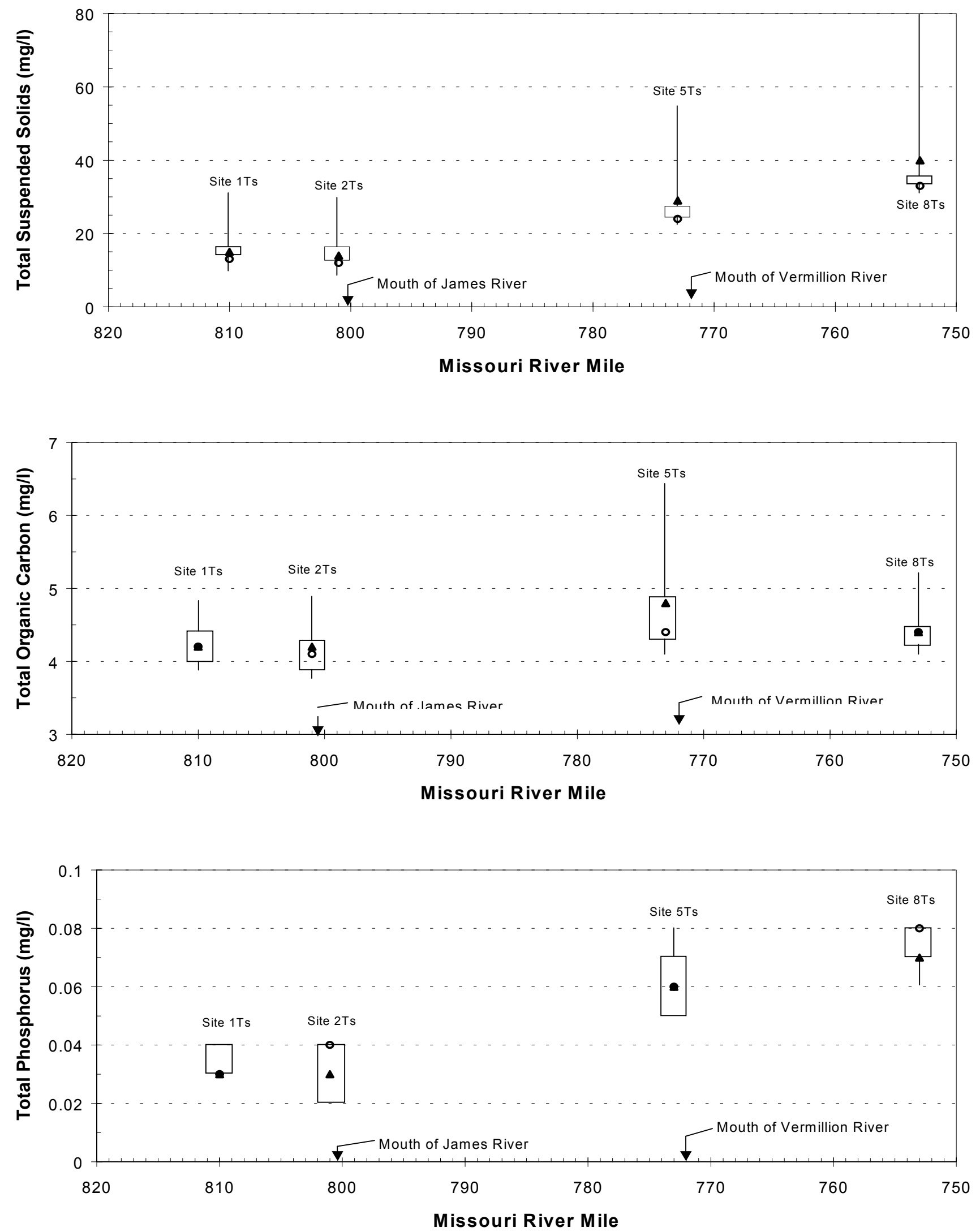

Figure 9. (Continued.) 

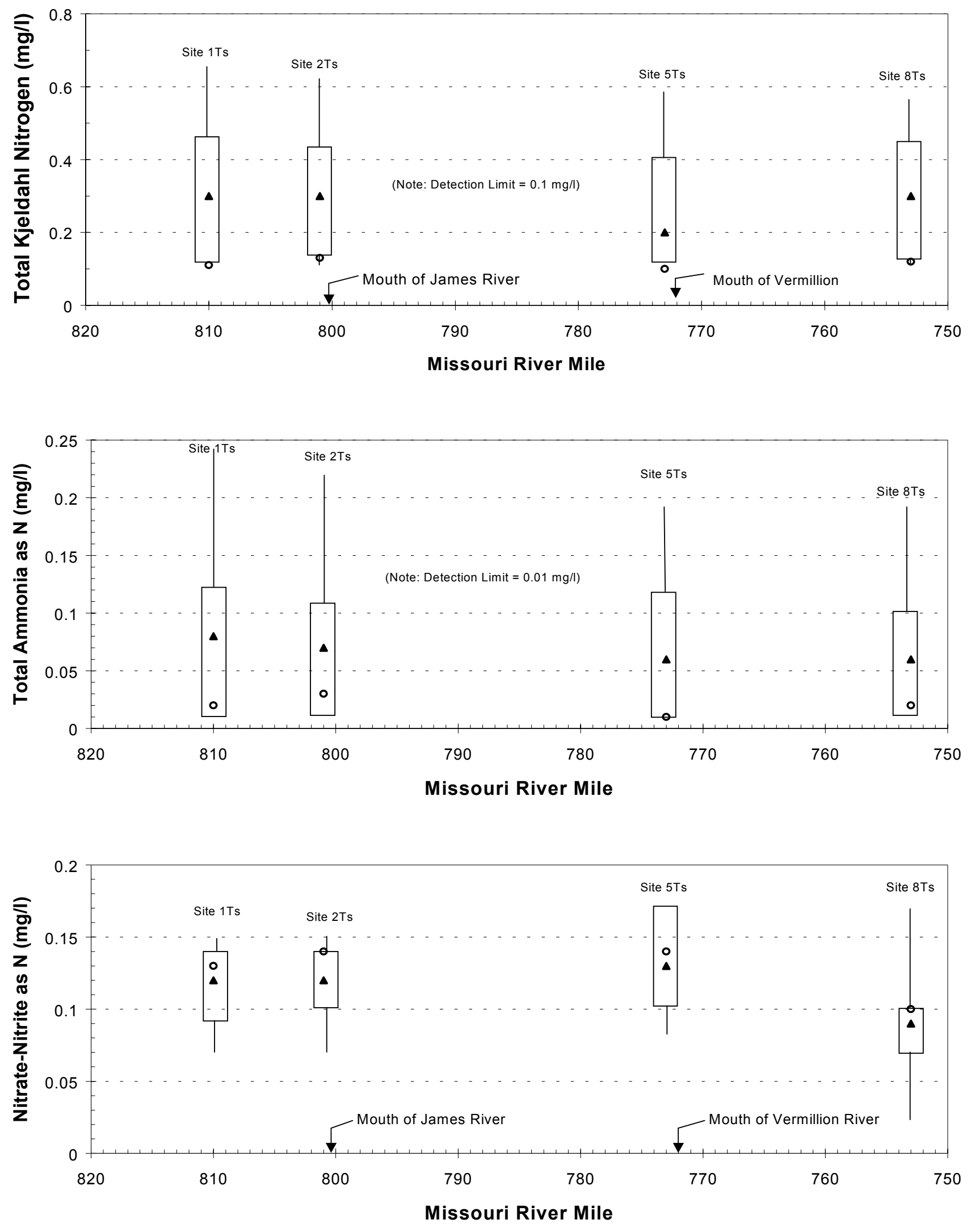

Figure 9. (Continued.) 

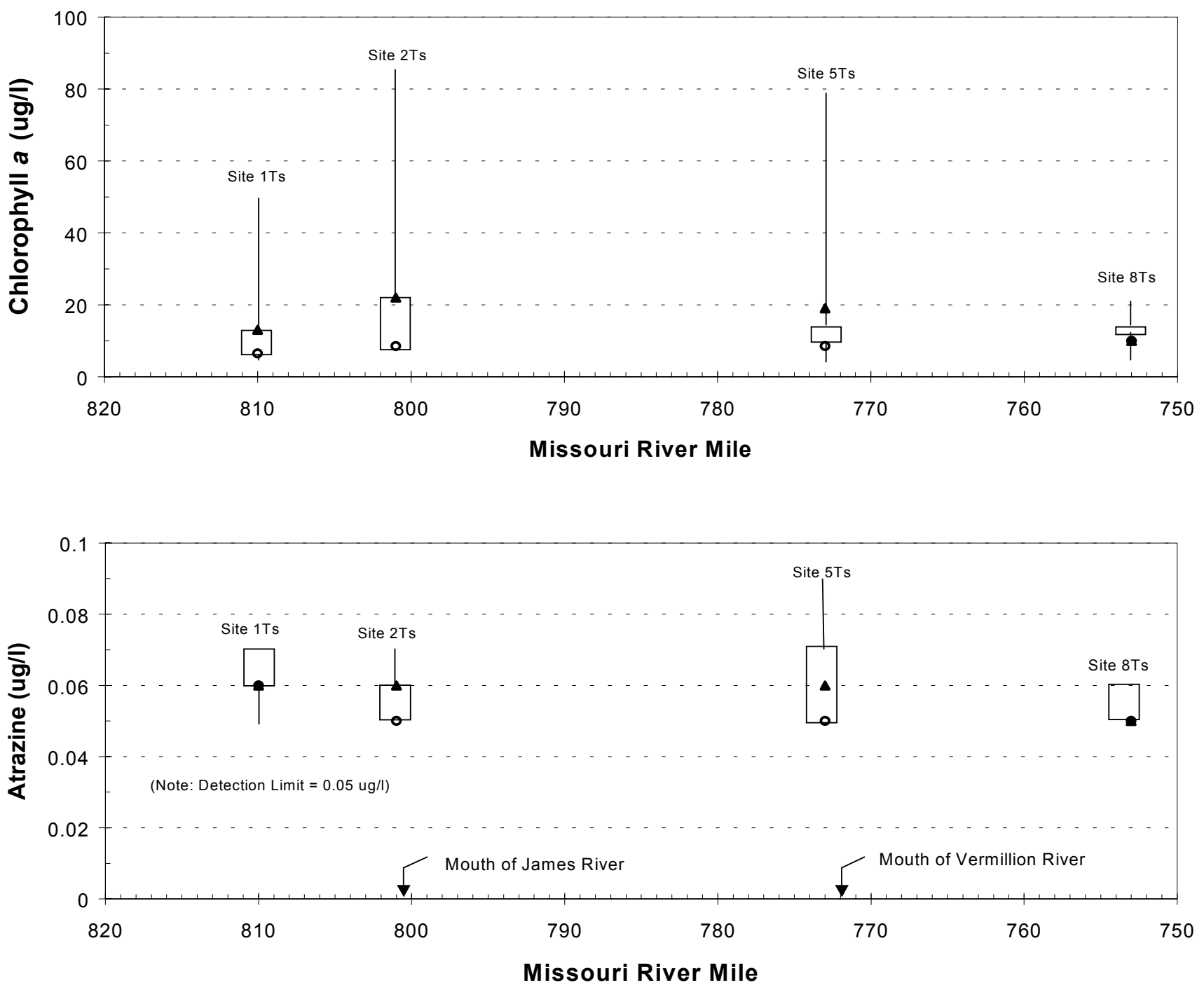

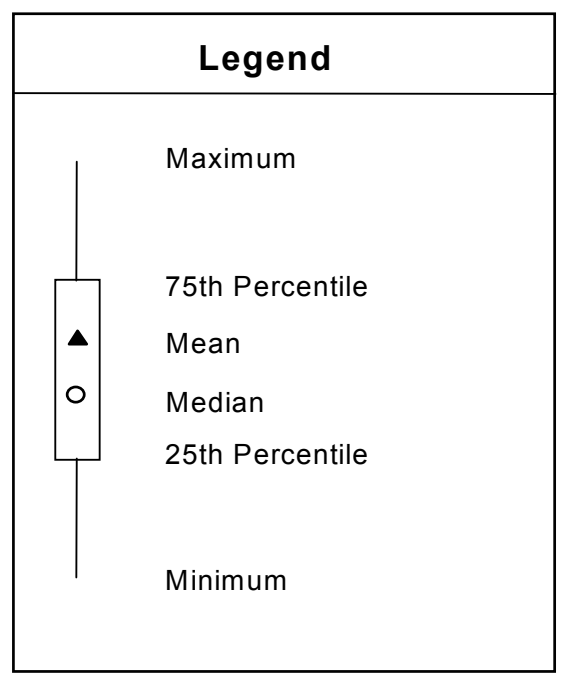

Figure 9. (Continued.) 


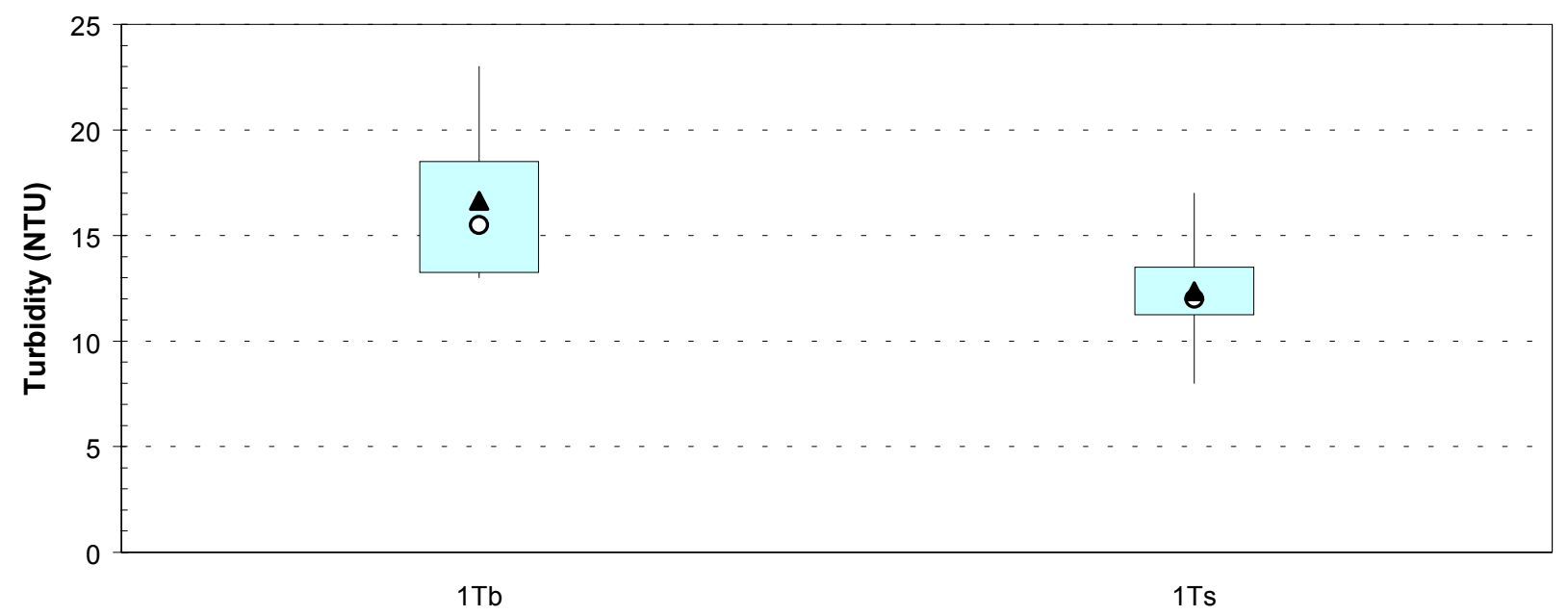

Monitoring Site
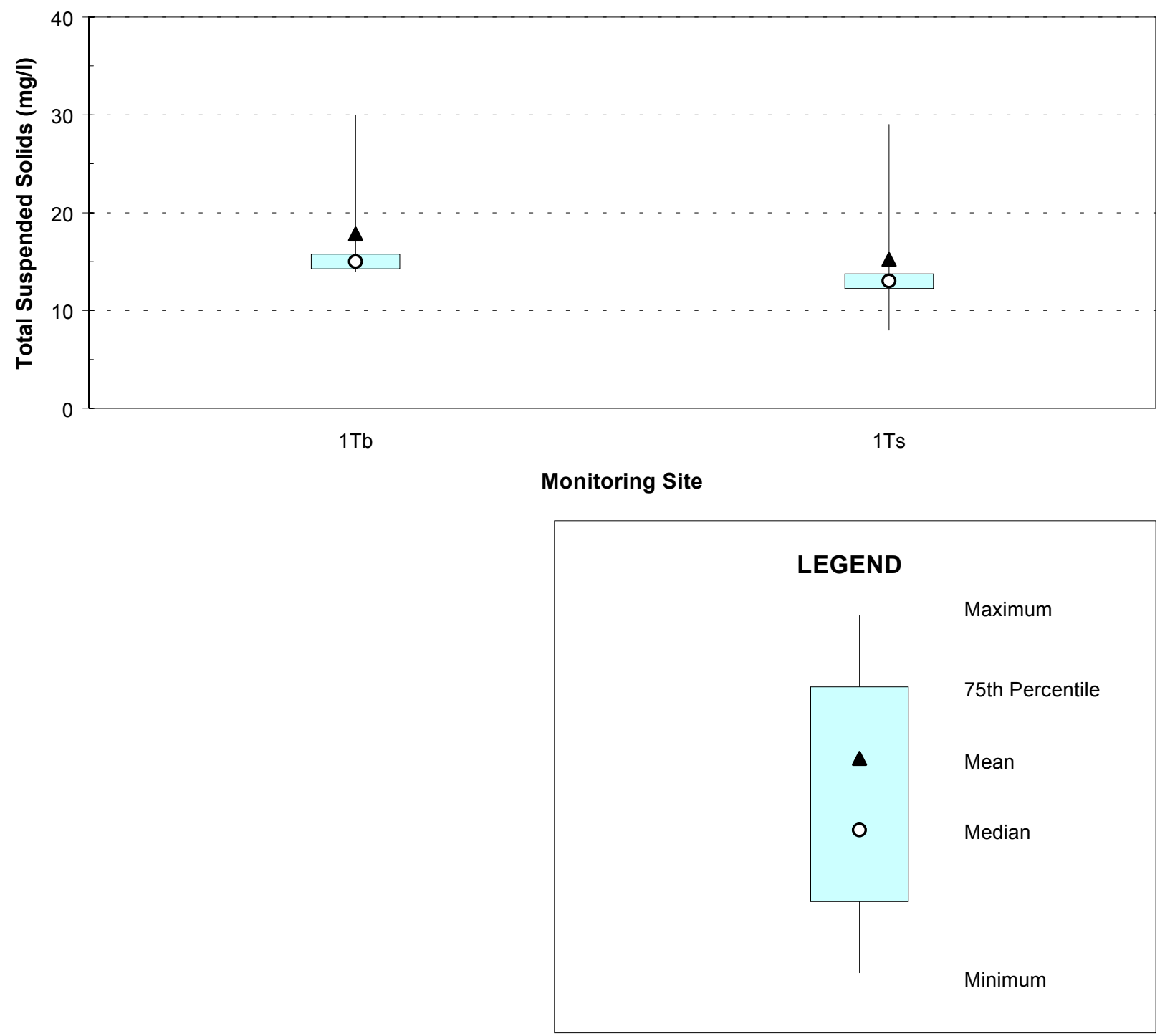

Figure 10. Boxplots of turbidity and total suspended solids levels for the near-bottom and near-surface thalweg samples collected at monitoring location 1. 

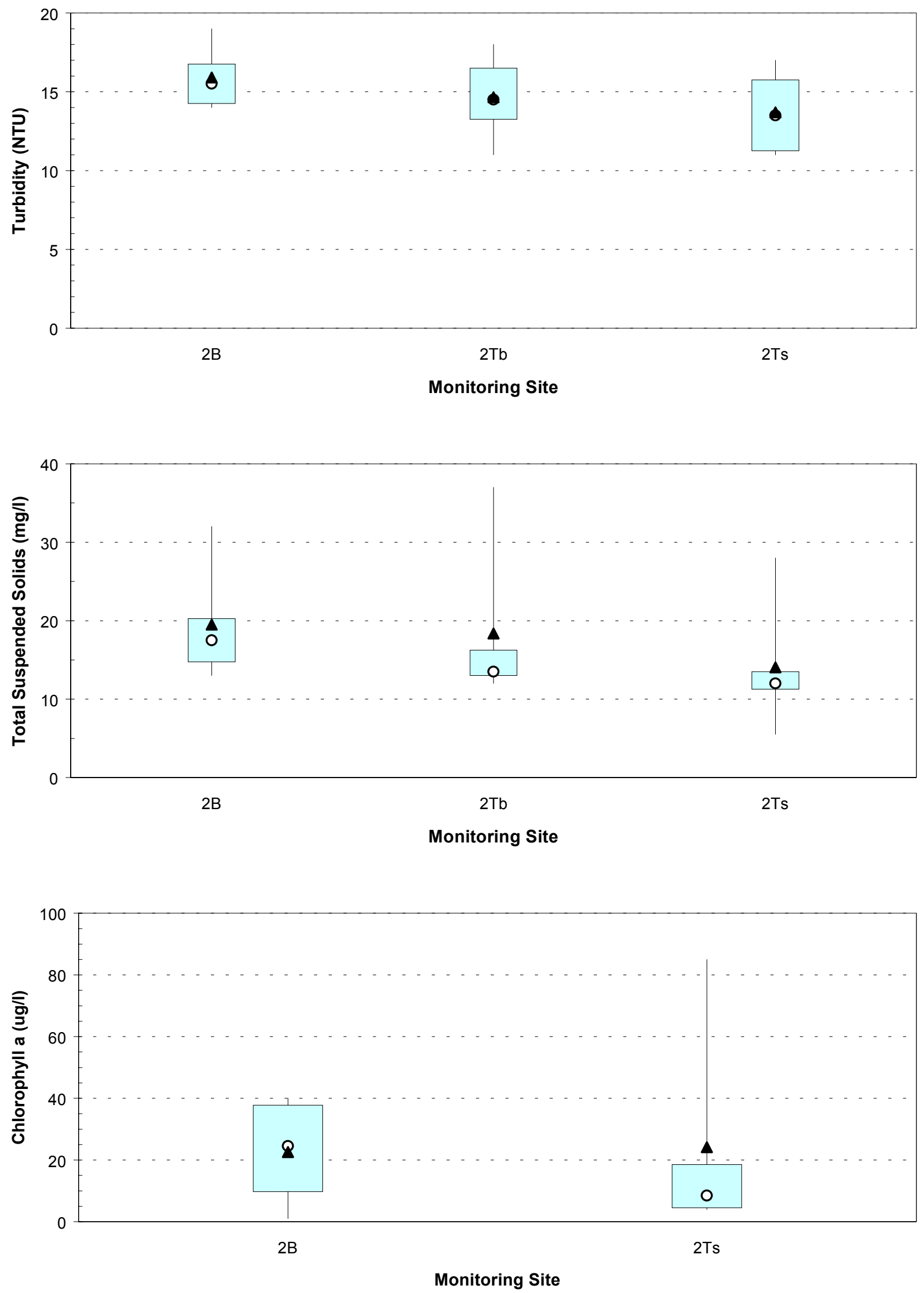

Figure 11. Boxplots of turbidity, total suspended solids, and chlorophyll a levels for the backwater and nearbottom and near-surface thalweg samples collected at monitoring location 2 . 

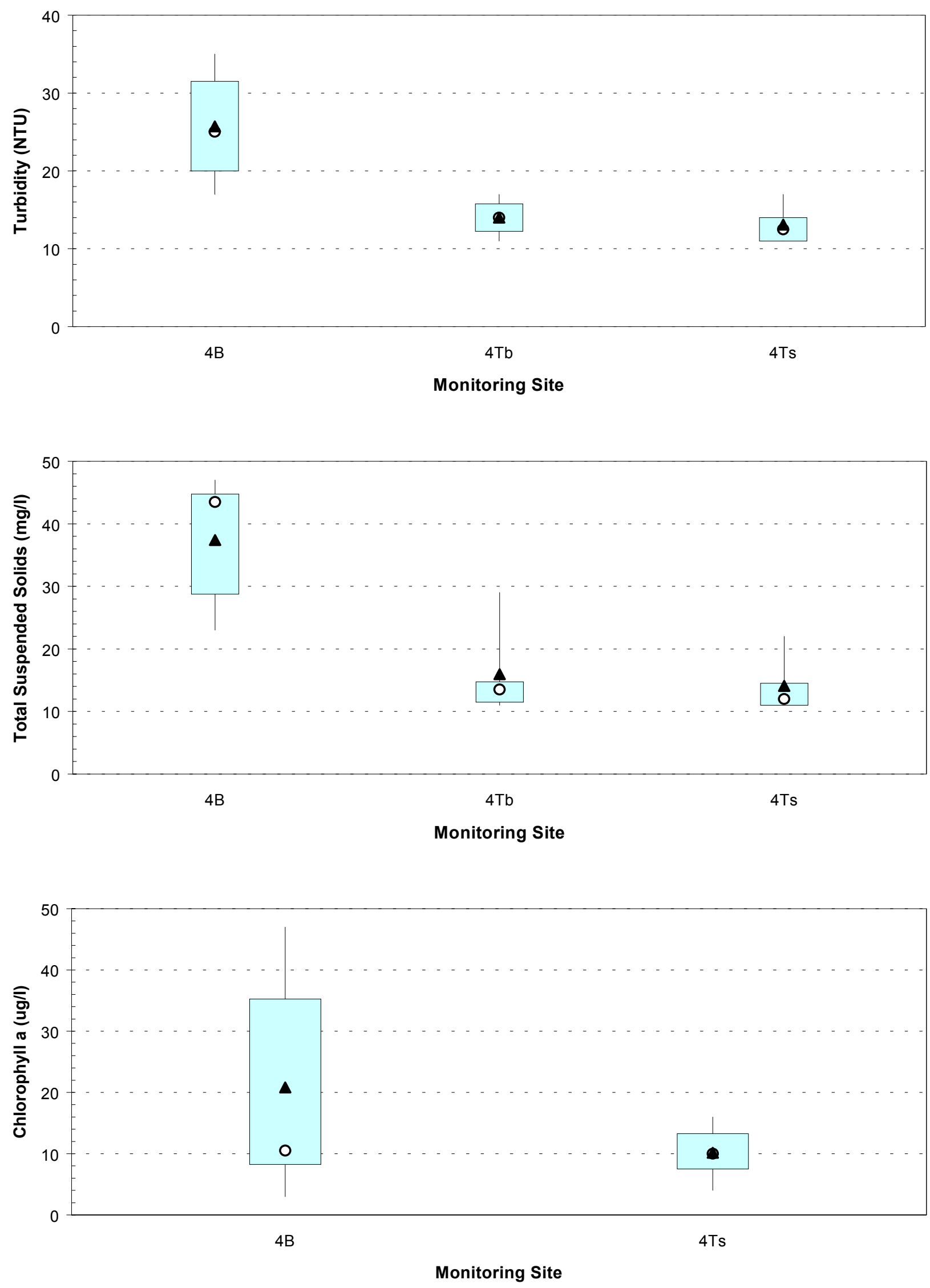

Figure 12. Boxplots of turbidity, total suspended solids, and chlorophyll a levels for the backwater and nearbottom and near-surface thalweg samples collected at monitoring location 4 . 

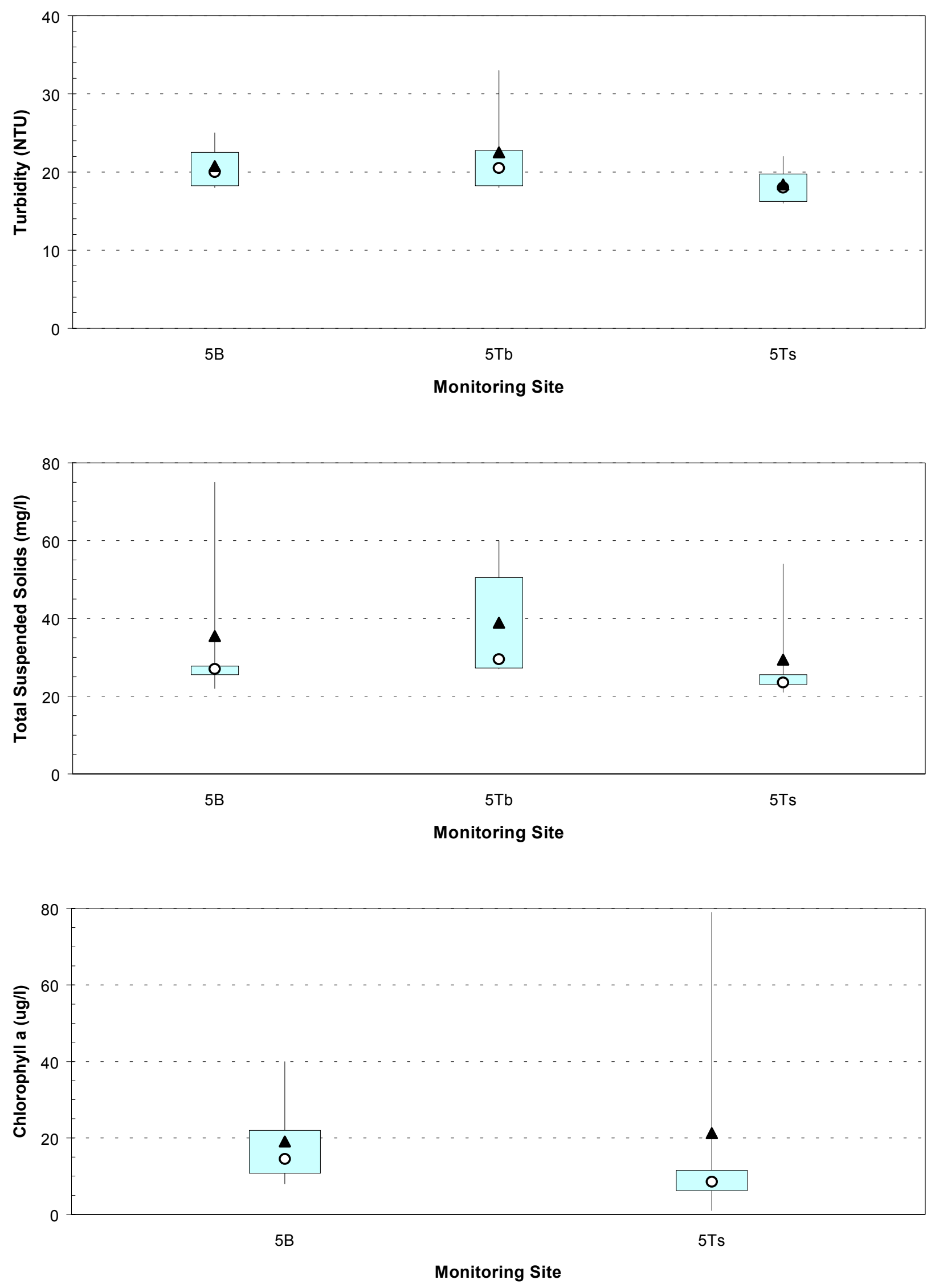

Figure 13. Boxplots of turbidity, total suspended solids, and chlorophyll a levels for the backwater and nearbottom and near-surface thalweg samples collected at monitoring location 5. 

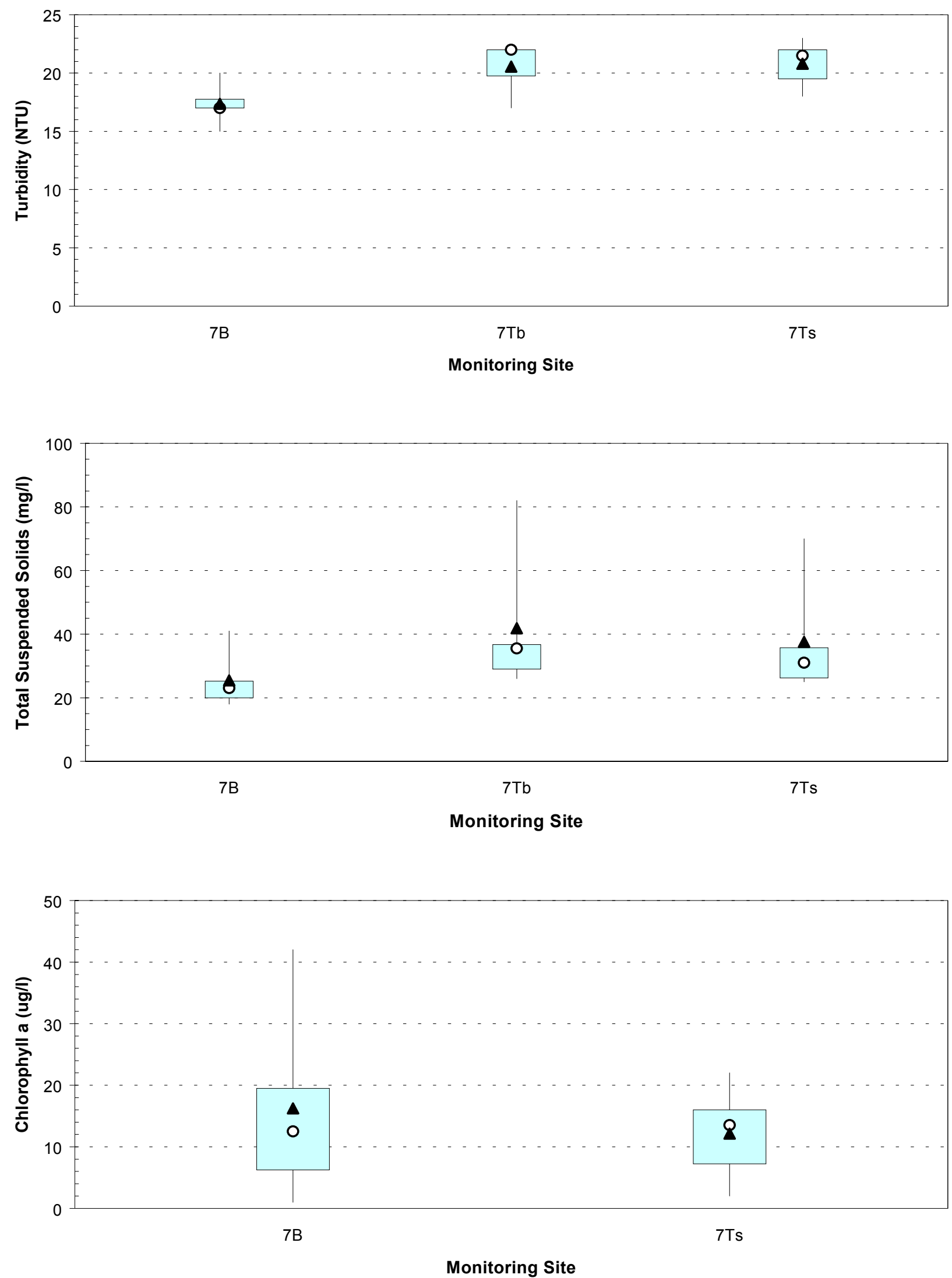

Figure 14. Boxplots of turbidity, total suspended solids, and chlorophyll a levels for the backwater and nearbottom and near-surface thalweg samples collected at monitoring location 7. 

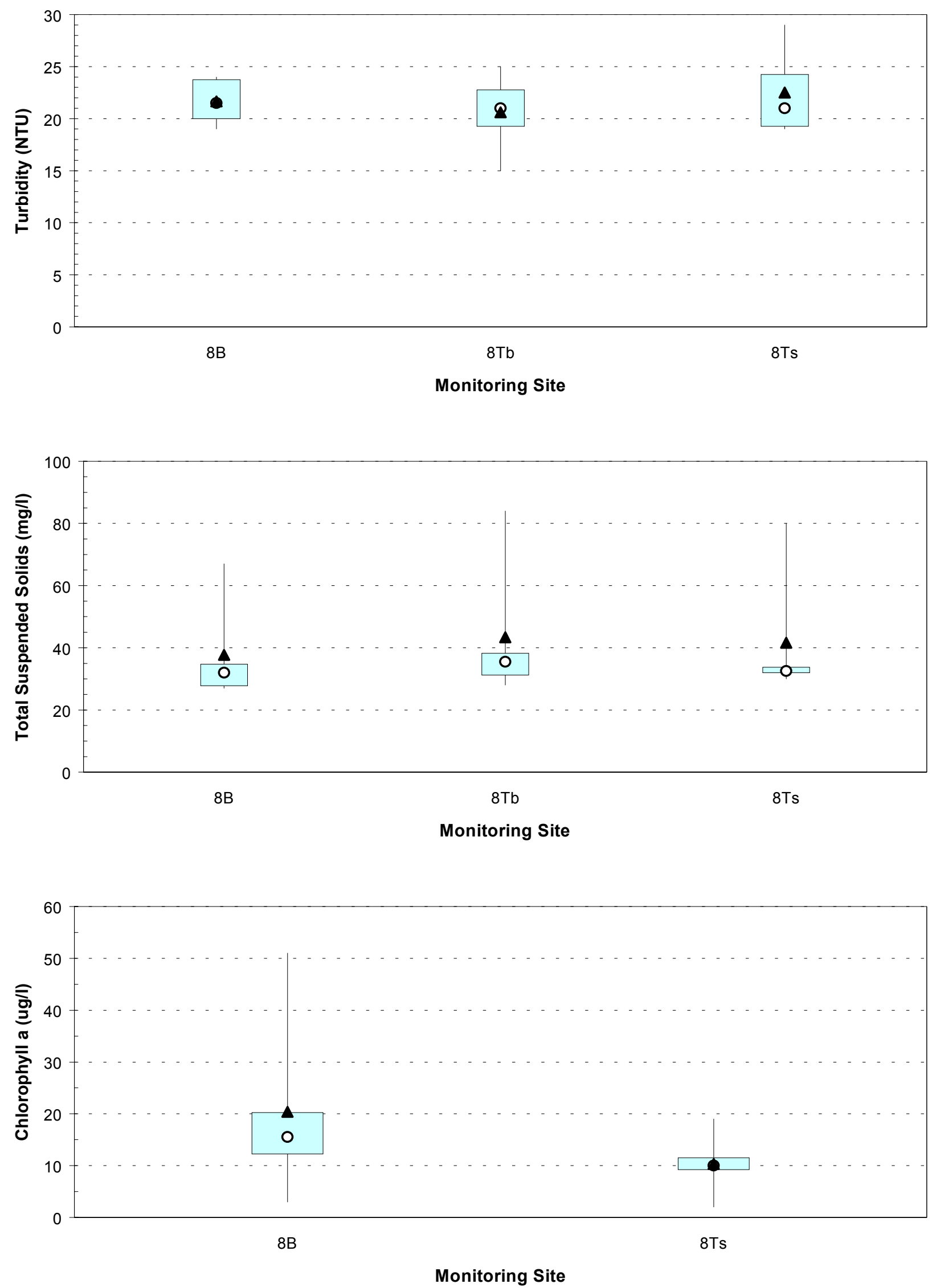

Figure 15. Boxplots of turbidity, total suspended solids, and chlorophyll a levels for the backwater and nearbottom and near-surface thalweg samples collected at monitoring location 8. 


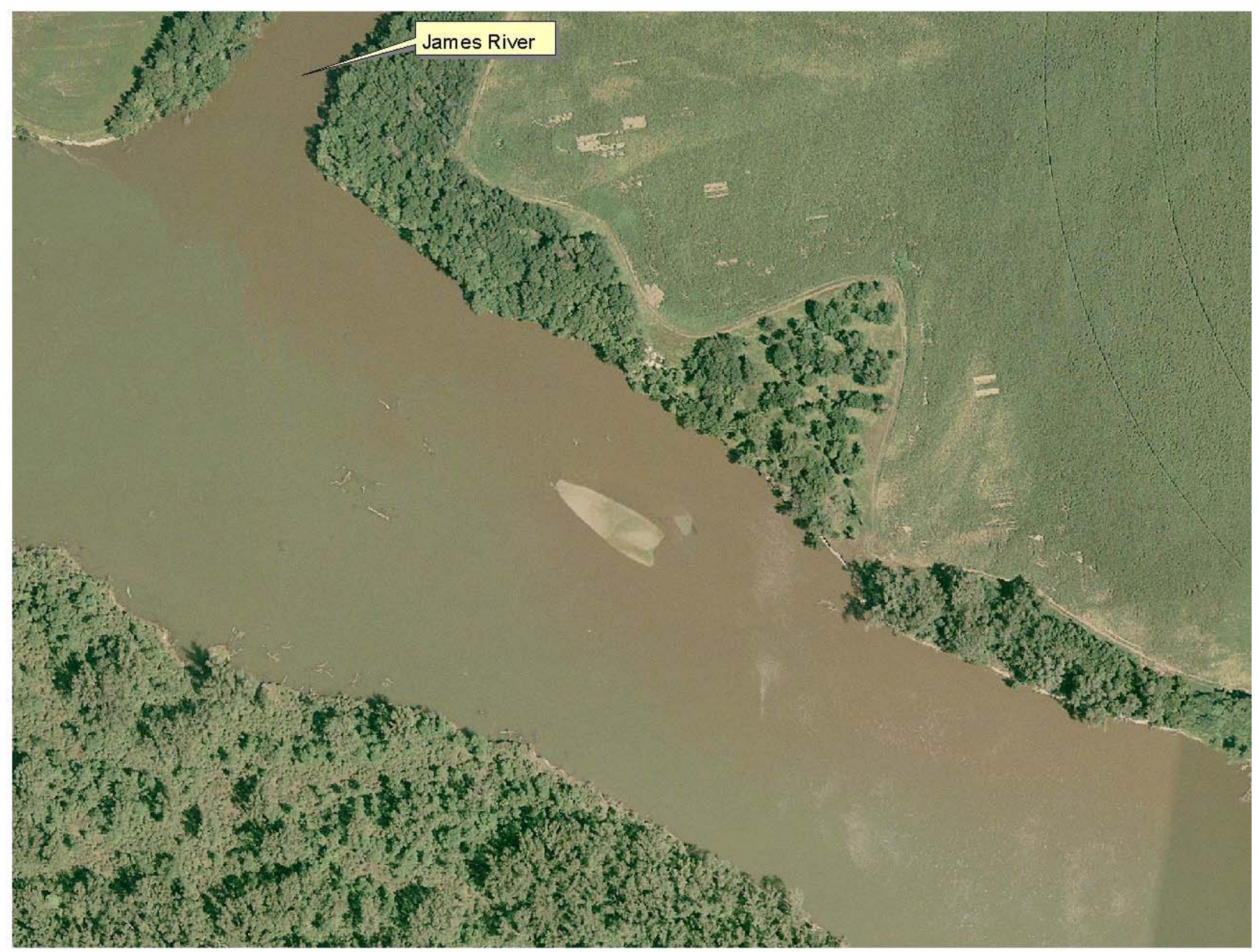

Plate 16. Area near the mouth of the James River as it enters a side channel of the Missouri River as depicted in a 1997 orthophoto of the area. 